\title{
Burial History, Thermal Maturity, and Oil and Gas Generation History of Source Rocks in the Bighorn Basin, Wyoming and Montana
}

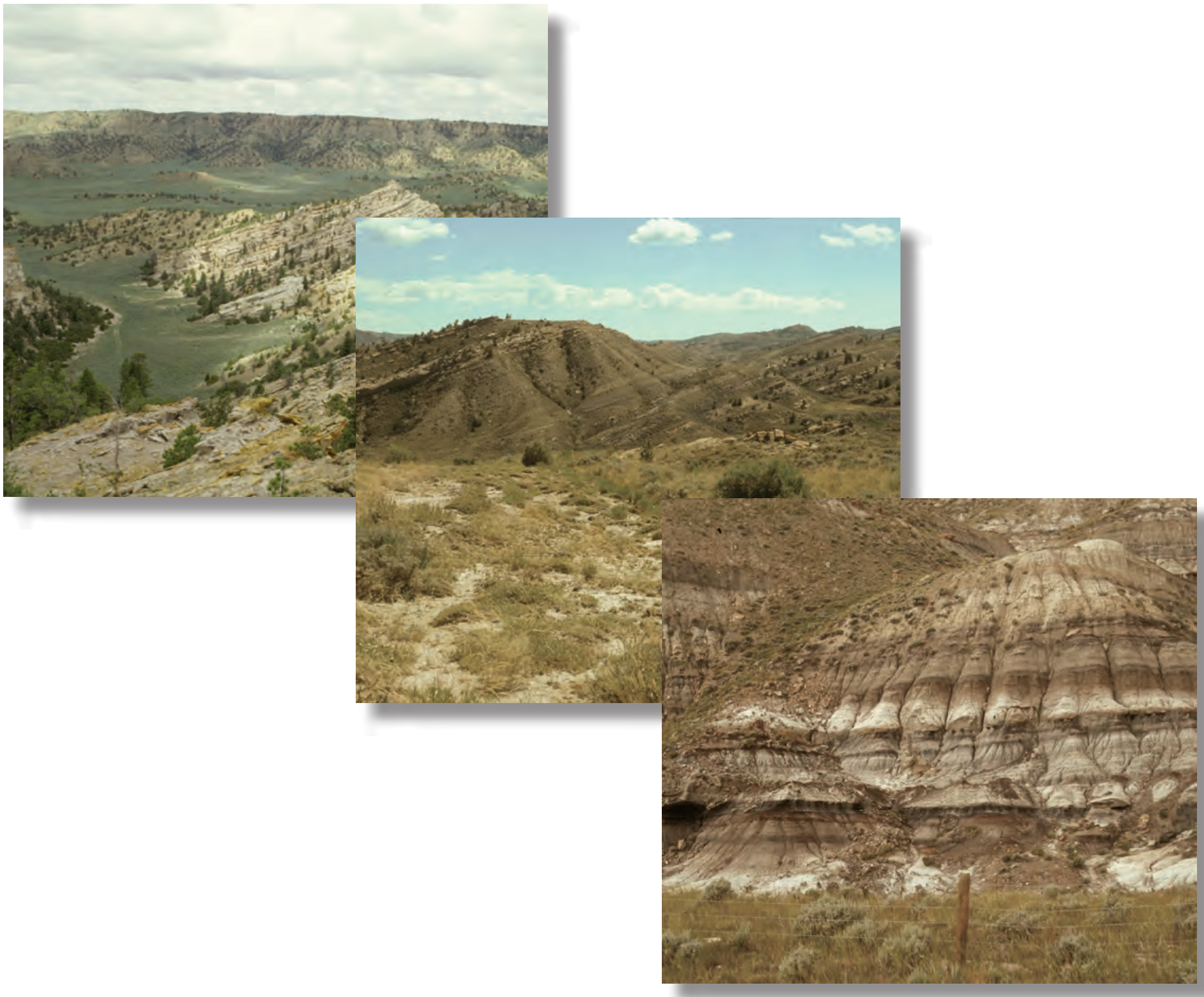

Scientific Investigations Report 2008-5037 
Photographs by R.C. Johnson, U.S. Geological Survey, Energy Team 


\section{Burial History, Thermal Maturity, and Oil and Gas Generation History of Source Rocks in the Bighorn Basin, Wyoming and Montana}

By Laura N.R. Roberts, Thomas M. Finn, Michael D. Lewan, and Mark A. Kirschbaum

Scientific Investigations Report 2008-5037 


\title{
U.S. Department of the Interior DIRK KEMPTHORNE, Secretary
}

\author{
U.S. Geological Survey \\ Mark D. Myers, Director
}

U.S. Geological Survey, Reston, Virginia: 2008

\begin{abstract}
About USGS Products
For product and ordering information:

World Wide Web: http://www.usgs.gov/pubprod

Telephone: 1-888-ASK-USGS

For more information on the USGS - the Federal source for science about the Earth, its natural and living resources, natural hazards, and the environment:

World Wide Web: http://www.usgs.gov

Telephone: 1-888-ASK-USGS

Suggested citation:

Roberts, Laura N.R., Finn, Thomas M., Lewan, Michael D., and Kirschbaum, M.A., 2008, Burial History, Thermal Maturity, and Oil and Gas Generation History of Source Rocks in the Bighorn Basin, Wyoming and Montana: U.S. Geological Survey Scientific Investigations Report 2008-5037, 28 p.

Any use of trade, product, or firm names is for descriptive purposes only and does not imply endorsement by the U.S. Government.

Although this report is in the public domain, permission must be secured from the individual copyright owners to reproduce any copyrighted materials contained within this report.
\end{abstract}




\section{Contents}

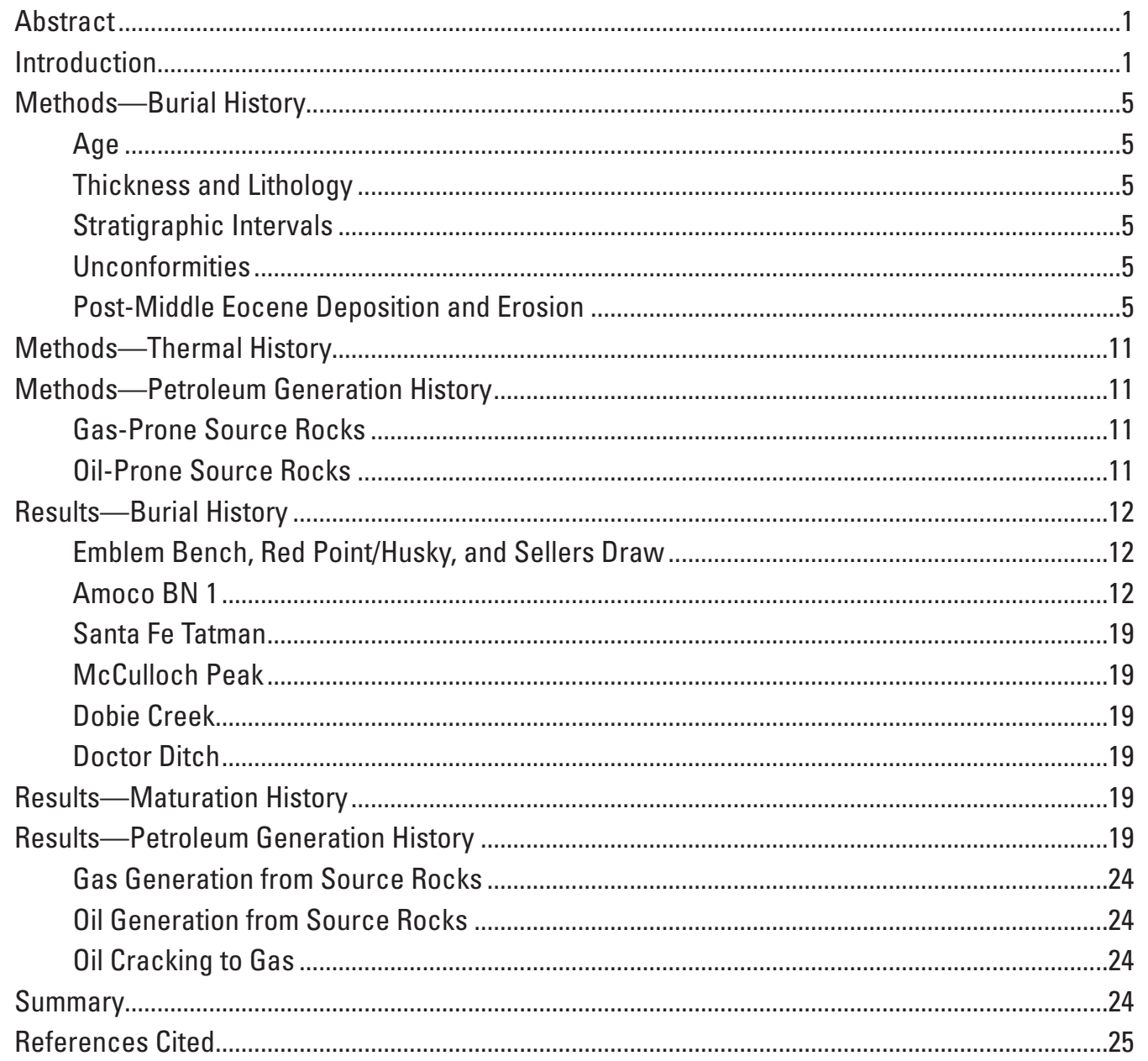




\section{Figures}

1. Base map of Bighorn Basin, Wyoming and Montana, showing eight burial history locations and structure contours on top of the Cloverly Formation.

2. Generalized stratigraphic chart of Pennsylvanian (part) through middle Tertiary (part) rocks in the Bighorn Basin, Wyoming and Montana

3. Maps and cross section showing method used to estimate post-middle Eocene deposition and erosion in the Bighorn Basin, Wyoming and Montana. $A$, trend surface using elevations of erosion surfaces described in Hagen and Surdam (1984) and Roberts and others (2007) and locality of Miocene vertebrates at Darton's Bluff. $B$, cross section showing estimated basin fill. $C$, isopach map of estimated post-middle Eocene erosion

4. Burial history curves at eight locations in the Bighorn Basin, Wyoming and Montana. $A$, locations where source rocks were most deeply buried. $B$, locations where source rocks were buried to intermediate depths, $C$, locations where source rocks were buried to shallowest depths

5. Timing of gas generation from Type-III source rocks for each source rock and burial history location in the Bighorn Basin, Wyoming and Montana.

6. Timing of oil and gas generation from Type-II source rocks for each source rock and burial history location in the Bighorn Basin, Wyoming and Montana

\section{Tables}

1. Information on wells used for burial history curves, Bighorn Basin, Wyoming and Montana

2. Data used to generate burial history curves for eight locations, Bighorn Basin, Wyoming and Montana

3. Present-day depth, calculated maximum depth of burial, and calculated temperature at maximum depth of burial for base of source rock intervals and for Phosphoria/Park City Formation from burial history reconstructions, Bighorn Basin, Wyoming and Montana

4. Timing of gas generation for Type-III source rocks at burial history locations, Bighorn Basin, Wyoming and Montana..

5. Timing of oil generation for Type-Il source rocks and timing of oil cracking to gas, Bighorn Basin, Wyoming and Montana 


\title{
Burial History, Thermal Maturity, and Oil and Gas Generation History of Source Rocks in the Bighorn Basin, Wyoming and Montana
}

\author{
By Laura N.R. Roberts, Thomas M. Finn, Michael D. Lewan, and Mark A. Kirschbaum
}

\section{Abstract}

Burial history, thermal maturity, and timing of oil and gas generation were modeled for seven key source-rock units at eight well locations throughout the Bighorn Basin in Wyoming and Montana. Also modeled was the timing of cracking to gas of Phosphoria Formation-sourced oil in the Permian Park City Formation reservoirs at two well locations. Within the basin boundary, the Phosphoria is thin and only locally rich in organic carbon; it is thought that the Phosphoria oil produced from Park City and other reservoirs migrated from the IdahoWyoming thrust belt. Other petroleum source rocks include the Cretaceous Thermopolis Shale, Mowry Shale, Frontier Formation, Cody Shale, Mesaverde and Meeteetse Formations, and the Tertiary (Paleocene) Fort Union Formation.

Locations (wells) selected for burial history reconstructions include three in the deepest parts of the Bighorn Basin (Emblem Bench, Red Point/Husky, and Sellers Draw), three at intermediate depths (Amoco BN 1, Santa Fe Tatman, and McCulloch Peak), and two at relatively shallow locations (Dobie Creek and Doctor Ditch). The thermal maturity of source rocks is greatest in the deep central part of the basin and decreases to the south, east, and north toward the basin margins. The Thermopolis and Mowry Shales are predominantly gas-prone source rocks, containing a mix of Type-III and Type-II kerogens. The Frontier, Cody, Mesaverde, Meeteetse, and Fort Union Formations are gas-prone source rocks containing Type-III kerogen. Modeling results indicate that in the deepest areas, (1) the onset of petroleum generation from Cretaceous rocks occurred from early Paleocene through early Eocene time, (2) peak petroleum generation from Cretaceous rocks occurred during Eocene time, and (3) onset of gas generation from the Fort Union Formation occurred during early Eocene time and peak generation occurred from late Eocene to early Miocene time. Only in the deepest part of the basin did the oil generated from the Thermopolis and Mowry Shales start generating gas from secondary cracking, which occurred in the late Eocene to Miocene. Also, based on modeling results, gas generation from the cracking of Phosphoria oil reservoired in the Park City Formation began in the late Eocene in the deep part of the basin but did not anywhere reach peak generation.

\section{Introduction}

The Bighorn Basin is a large Laramide (Late Cretaceous through Eocene) structural and sedimentary basin that encompasses about 7,500 $\mathrm{mi}^{2}$ in north-central Wyoming and south-central Montana (fig. 1). The basin boundaries are defined by fault- and fold-bounded Laramide uplifts that surround it except in the northernmost part where the basin is bounded by the northwest-trending Nye-Bowler Lineament. Adjacent mountain ranges include the Beartooth Mountains to the northwest, the Absaroka Mountains to the west, the Owl Creek Mountains to the south, and the Bighorn Mountains to the east (fig. 1). This report summarizes the burial history, thermal maturity, and timing of petroleum generation at eight locations (table 1) for seven key source-rock intervals throughout the basin. The petroleum source-rock intervals studied are (1) the Cretaceous Thermopolis Shale, (2) Mowry Shale, (3) Frontier Formation, (4) Cody Shale, (5) Mesaverde Formation, (6) Meeteetse Formation, and (7) the Tertiary (Paleocene) Fort Union Formation (fig. 2). Also modeled was the timing of cracking to gas of Phosphoria-sourced oil in the Permian Park City Formation reservoirs at two well locations. The resulting data and interpretations support the assessment of undiscovered oil and gas resources of the Bighorn Basin undertaken by the U.S. Geological Survey.

Previous studies of the burial/thermal history of parts of the Bighorn Basin were presented in Hagen and Surdam (1984), Hagen (1986), Ryder (1987), and Nuccio and Finn (1998). All wells examined by Hagen and Surdam (1984) are confined to the northern part of the basin, and their interval of study included only Thermopolis, Mowry, Frontier, and Cody strata. Hagen (1986) discussed only burial/thermal history as it relates to oil generation from the Mowry Shale in the northern part of the basin. Ryder (1987) presented time-temperature reconstructions for two wells in a small area just north of the central part of the basin, and Nuccio and Finn (1998) presented thermal maturity data for Cretaceous and Tertiary source rocks across the basin. 


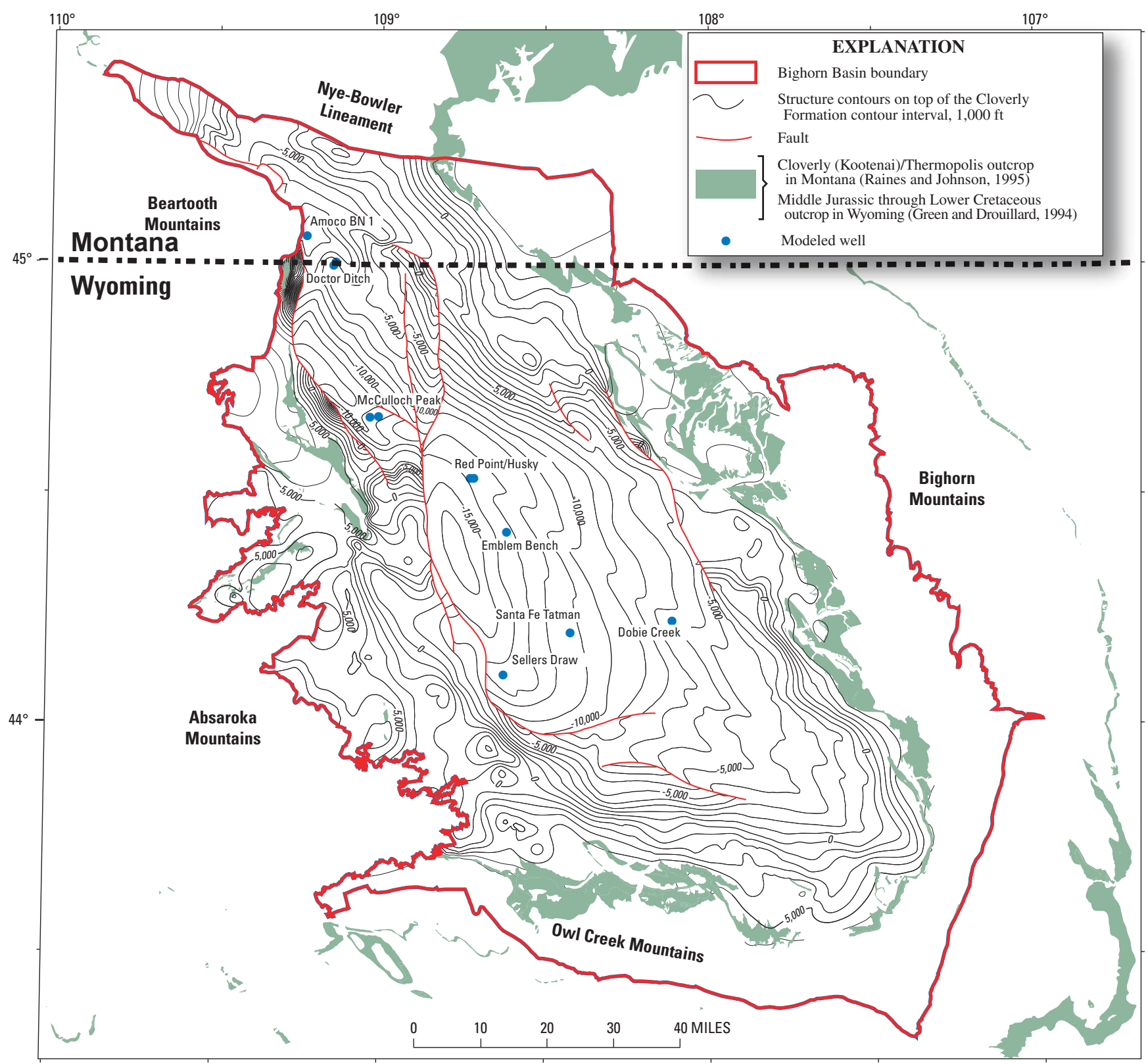

Figure 1. Base map of Bighorn Basin, Wyoming and Montana, showing eight burial history locations and structure contours on top of the Cloverly Formation. 
Table 1. Information on wells used for burial history curves, Bighorn Basin, Wyoming and Montana.

[Map name is shortened well name for use on figures, in tables, and for discussion in text. Asterisk indicates data were composited from two wells. N, north; S, south; E, east; W, west; KB, Kelly bushing in feet; GL, ground level in feet; DF, derrick floor in feet; TD, total depth in feet]

\begin{tabular}{|c|c|c|c|c|c|c|c|c|c|c|}
\hline Map name & Operator & Lease & Well & Section & Township & Range & Elevation & TD & County & State \\
\hline Emblem Bench & Forest Oil Corp. & Emblem Bench & 1 & 2 & $51 \mathrm{~N}$ & 98W & $5,224(\mathrm{~KB})$ & 18,636 & Park & WY \\
\hline Red Point/Husky* & Texas Pacific Oil & Red Point II Unit & 1 & 30 & $53 \mathrm{~N}$ & 98W & $5,270(\mathrm{~KB})$ & 18,500 & Park & WY \\
\hline Red Point/Husky* & Husky Oil & Unit & $14-25$ & 25 & $53 \mathrm{~N}$ & 99W & $5,304(\mathrm{~KB})$ & 15,914 & Park & WY \\
\hline Sellers Draw & Amercan Quasar Petro & Sellers Draw Unit & 1 & 21 & $48 \mathrm{~N}$ & 98W & $5,874(\mathrm{~KB})$ & 23,081 & Park & WY \\
\hline Santa Fe Tatman & Santa Fe Energy Corp. & Tatman Mtn Federal & $1-20$ & 20 & $49 \mathrm{~N}$ & $96 \mathrm{~W}$ & $4,662(\mathrm{~KB})$ & 16,145 & Big Horn & WY \\
\hline McCulloch Peak* & Mich Wisc Pipe Line & McCulloch Peak II & $2-9$ & 9 & $54 \mathrm{~N}$ & $101 \mathrm{~W}$ & $5,142(\mathrm{~KB})$ & 14,964 & Park & WY \\
\hline McCulloch Peak* & CIG Exploration & McCulloch Peak & 1 & 10 & $54 \mathrm{~N}$ & $101 \mathrm{~W}$ & $4,977(\mathrm{~KB})$ & 15,300 & Park & WY \\
\hline Amoco BN 1 & Amoco Prod Co. & Amoco-BN & 1 & 11 & $9 \mathrm{~S}$ & $20 \mathrm{E}$ & $6,140(\mathrm{~KB})$ & 14,848 & Carbon & MT \\
\hline Dobie Creek & Exxcel Energy & Dobie Creek Unit & $1-11$ & 11 & $49 \mathrm{~N}$ & $94 W$ & $4,457(\mathrm{~KB})$ & 10,805 & Big Horn & WY \\
\hline Doctor Ditch* & Gas Prod. Entp Inc. & Burlington Northern & $23-58-102$ & 23 & $58 \mathrm{~N}$ & $102 \mathrm{~W}$ & $4,714(\mathrm{GL})$ & 13,604 & Park & WY \\
\hline Doctor Ditch* & Phillips Petroleum Co. & NP & $A-1$ & 33 & $9 \mathrm{~S}$ & $21 \mathrm{E}$ & $4678(\mathrm{DF})$ & 13,830 & Carbon & MT \\
\hline
\end{tabular}



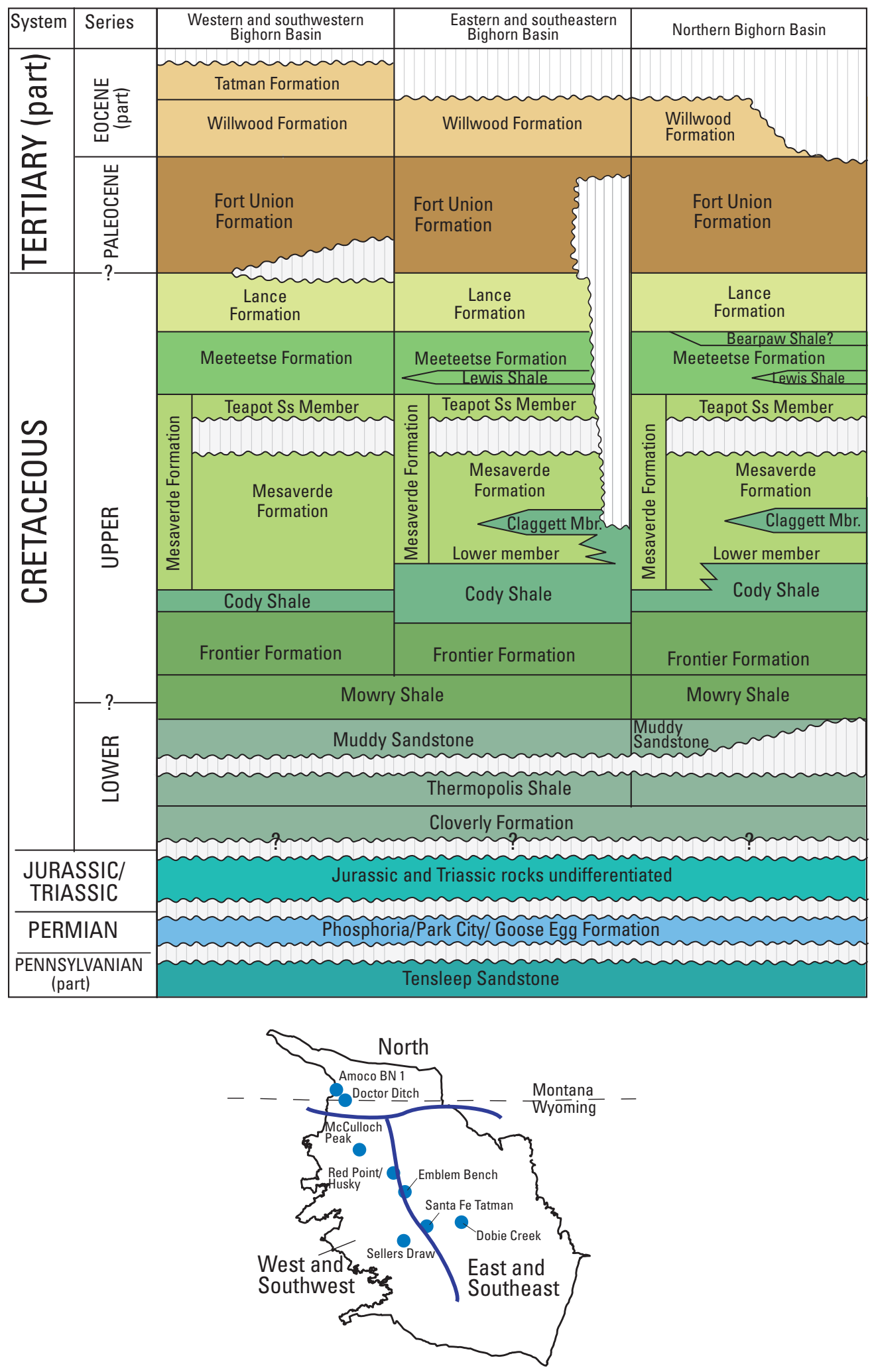

Figure 2. Generalized stratigraphic chart of Pennsylvanian (part) through middle Tertiary (part) rocks in the Bighorn Basin, Wyoming and Montana. Time spans and thicknesses not shown in correct proportions. Hatching indicates time periods of erosion or nondeposition; wavy line represents unconformity. Inset map shows burial history locations and basin subdivisions. 


\section{Methods-Burial History}

One-dimensional (1-D) modeling of burial history and thermal maturity was performed for eight well locations (fig. 1, table 1) using PetroMod1D ${ }^{\circledR}$ (version 9.0) of Integrated Exploration Systems (2005) GmbH (IES), Germany. The well locations were chosen because they (1) were drilled to depths that penetrated a significant part of the geologic section of interest, (2) represent different geologic settings within the basin, and (3) have measured vitrinite reflectance and downhole temperature data to aid in calibrating maturation models.

\section{Age}

Ages of stratigraphic units older than the Cretaceous Cloverly Formation (table 2) were estimated using Love and others (1993) as a guide for the ages of stratigraphic units and ages of regional unconformities throughout the Bighorn Basin. Table 2 shows the age, thickness, and generalized lithologic data used to construct the burial history curves. The ages at system and series boundaries were adjusted to the 1999 Geologic Time Scale (Palmer and Geissman, 1999).

\section{Thickness and Lithology}

Thicknesses of the stratigraphic units in the subsurface were interpreted from geophysical well logs or were determined from tops of units recorded in the Petroleum Information/Dwights PetroROM well-history database (IHS Energy Group, 2004). Lithologies of the stratigraphic units were interpreted from geophysical well logs and American Stratigraphic Company lithology logs and from published cross sections (Keefer and others, 1998). The lithologies were generalized for modeling purposes (table 2).

\section{Stratigraphic Intervals}

The models include stratigraphic units from the base of the Permian Phosphoria Formation through the middle Eocene Tatman Formation at the surface. The Triassic and Jurassic sections do not contain major petroleum source rocks so were considered as a single unit (fig. 2). The Upper Cretaceous Mesaverde Formation consists of a lower part overlain by the Teapot Sandstone Member; in the eastern, southeastern, and northern parts of the basin, the Claggett Member of the Cody Shale is included in the lower part of the formation. The Upper Cretaceous Lewis Shale is present in the eastern, southeastern, and northern parts of the basin, where it is included with the Meeteetse Formation. The Bearpaw Shale, which is only in the northern part of the basin, also is included with the Meeteetse Formation in the models.

\section{Unconformities}

Figure 2 shows the major unconformities that were used for the burial history reconstructions. The area of the Bighorn Basin during the Permian through the Early Cretaceous (Lawton, 1994) existed in a relatively stable cratonic setting; therefore, the unconformities at the Permian-Triassic and JurassicCretaceous boundaries (Love and others, 1993) and within the Lower Cretaceous (Merewether and others, 1997) probably do not represent long enough periods of sedimentation and erosion to significantly affect either the thermal maturity of the reservoired oil of the underlying Phosphoria/Park City Formation or the thermal maturity of the Thermopolis Shale. At least one hiatus occurred during deposition of the Upper Cretaceous Frontier Formation (Love and others, 1993), when the area of the Bighorn Basin was in a distal foreland basin setting (Lawton, 1994) that prevented a sufficient amount of sedimentation and subsequent erosion to have taken place that would affect the thermal maturity of the underlying source rocks; therefore, a hiatus was not included in the model (and not shown in figure 2). We included a hiatus for the unconformity at the base of the Teapot Sandstone Member of the Mesaverde Formation that occurred from 78 to $73 \mathrm{Ma}$ (Merewether, 1996; and Merewether and others, 1997).

The erosional event within and at the base of the Paleocene Fort Union Formation depicted in figure 2 occurred toward the margins of the basin. We assumed continuous deposition across the Cretaceous-Tertiary boundary in the models, based on their locations, which are a considerable distance from the basin margin, and based on the premise that unconformities at the basin margins become less significant toward the interior, as is evidenced by the much greater thicknesses of the stratigraphic units involved.

\section{Post-Middle Eocene Deposition and Erosion}

No post-middle Eocene rocks are preserved in areas where the burial histories were reconstructed, and in the northern part of the basin no post-Paleocene rocks are preserved. Because of this, we made assumptions in regard to the amounts of post-middle Eocene and post-Paleocene sedimentation and erosion, based on a method described in Roberts and others (2007), to generate a trend surface of the minimum elevation of basin fill across the Bighorn Basin. Hagen and Surdam (1984, and references therein) described locations of subsummit erosion surfaces and of post-middle Eocene outcrops that they used to estimate the amount of erosion from the northern part of the basin for their study. We incorporated the locations used by Hagen and Surdam (1984) with those in the Absaroka Mountains (Roberts and others, 2007) to construct a first-order polynomial trend surface (fig. $3 A, B$ ) using EarthVision (Dynamic Graphics, Inc., 2005) that extends from surfaces in the Absarokas eastward to a locality of Miocene mammal fossils at an elevation of about $9,000 \mathrm{ft}$ on top of Darton's Bluff (fig. 3A) (sec. 19, T. 48 N., R. 85 W.) in the 
Table 2. Data used to generate burial history curves for eight locations, Bighorn Basin, Wyoming and Montana.

[Models only include stratigraphic units from the base of the Phosphoria Formation regardless of whether the well was drilled to deeper units. Mbr., Member; Fm., Formation; Ss., Sandstone; ft, feet; Ma, mega-annum; \%, percent; ss, sandstone; sh, shale; ls, limestone; slst, siltstone; dolo, dolomite. Heat flow and thermal gradient used to calibrate model are given for each location. $\mathrm{mW} / \mathrm{m}^{2}$, milliWatts per square meter; ${ }^{\circ} \mathrm{F}$, degrees Fahrenheit]

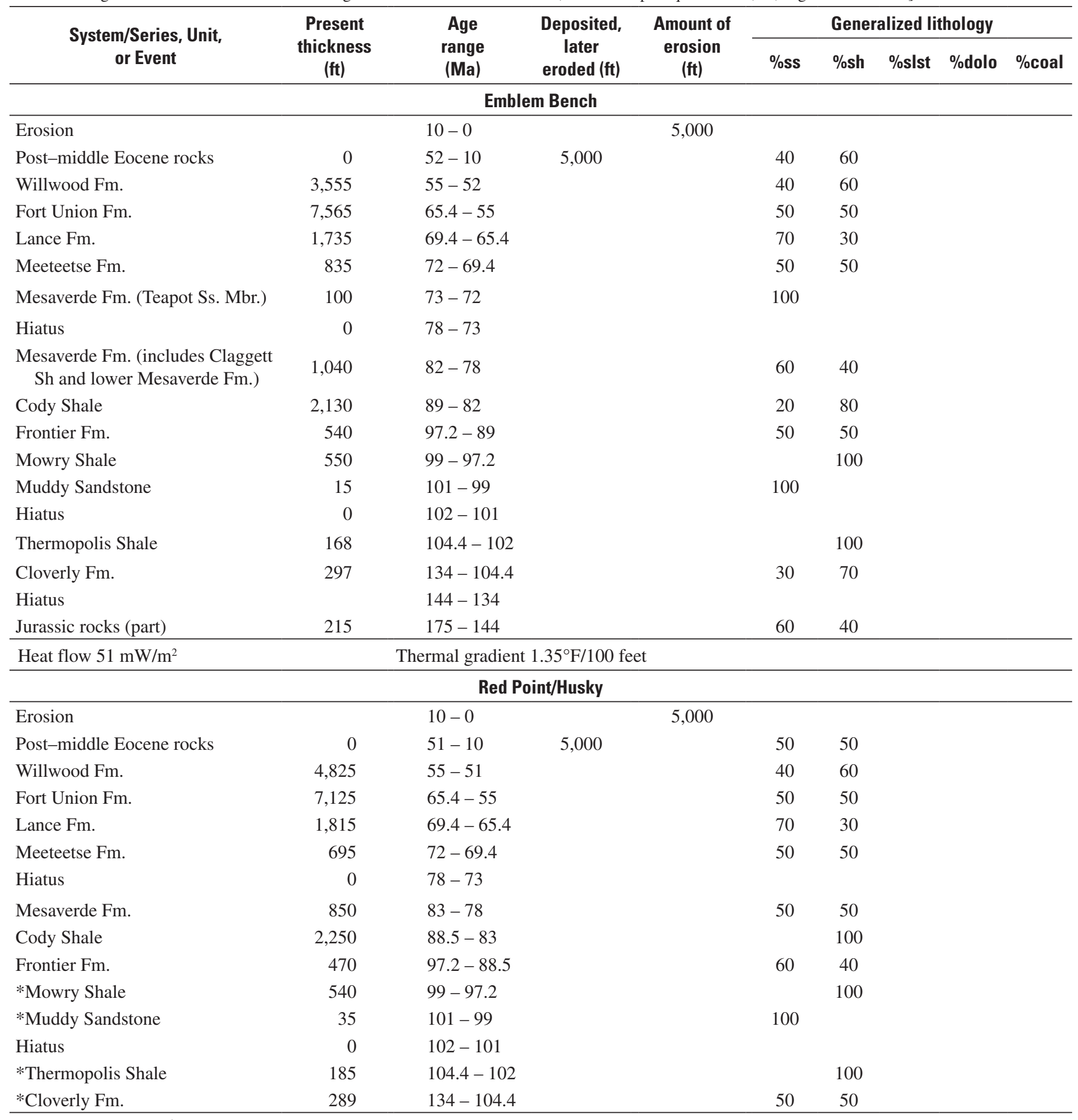

Heat flow $47 \mathrm{~mW} / \mathrm{m}^{2}$

Thermal gradient $1.25^{\circ} \mathrm{F} / 100$ feet

"Note: Thickness of Mowry, Muddy, Thermopolis, and Cloverly are projected from a nearby well. 
Table 2. Data used to generate burial history curves for eight locations, Bighorn Basin, Wyoming and Montana.—Continued

[Models only include stratigraphic units from the base of the Phosphoria Formation regardless of whether the well was drilled to deeper units. Mbr., Member; Fm., Formation; Ss., Sandstone; ft, feet; Ma, mega-annum; \%, percent; ss, sandstone; sh, shale; 1s, limestone; slst, siltstone; dolo, dolomite. Heat flow and thermal gradient used to calibrate model are given for each location. $\mathrm{mW} / \mathrm{m}^{2}$, milliWatts per square meter; ${ }^{\circ} \mathrm{F}$, degrees Fahrenheit]

\begin{tabular}{|c|c|c|c|c|c|c|c|c|c|}
\hline \multirow{2}{*}{$\begin{array}{c}\text { System/Series, Unit, } \\
\text { or Event }\end{array}$} & \multirow{2}{*}{$\begin{array}{c}\text { Present } \\
\text { thickness } \\
\text { (ft) }\end{array}$} & \multirow{2}{*}{$\begin{array}{l}\text { Age range } \\
\text { (Ma) }\end{array}$} & \multirow{2}{*}{$\begin{array}{c}\text { Deposited, } \\
\text { later } \\
\text { eroded }(\mathrm{ft})\end{array}$} & \multirow{2}{*}{$\begin{array}{c}\text { Amount of } \\
\text { erosion } \\
\text { (ft) }\end{array}$} & \multicolumn{5}{|c|}{ Generalized lithology } \\
\hline & & & & & $\% s s$ & $\%$ sh & $\%$ slst & \%dolo & \%coal \\
\hline \multicolumn{10}{|c|}{ Sellers Draw } \\
\hline Erosion & & $10-0$ & & 4,900 & & & & & \\
\hline Post-middle Eocene rocks & 0 & $51-10$ & 4,900 & & 50 & 50 & & & \\
\hline Tatman and Willwood Fms. & 5,080 & $55-51$ & & & 50 & 50 & & & \\
\hline Fort Union Fm. & 7,430 & $65.4-55$ & & & 50 & 50 & & & \\
\hline Lance Fm. & 1,250 & $69.4-65.4$ & & & 80 & 20 & & & \\
\hline Meeteetse Fm. & 1,255 & $72-69.4$ & & & 45 & 45 & & & 10 \\
\hline Mesaverde Fm. (Teapot Ss. Mbr.) & 135 & $73-72$ & & & 100 & & & & \\
\hline Hiatus & 0 & $78-73$ & & & & & & & \\
\hline Mesaverde Fm. & 1,040 & $83-78$ & & & 50 & 50 & & & \\
\hline Cody Shale & 2,440 & $88.5-83$ & & & & 100 & & & \\
\hline Frontier Fm. & 420 & $97.2-88.5$ & & & & 50 & 50 & & \\
\hline Mowry Shale & 515 & $99-97.2$ & & & & 100 & & & \\
\hline Muddy Sandstone & 45 & $101-99$ & & & 100 & & & & \\
\hline Hiatus & 0 & $102-101$ & & & & & & & \\
\hline Thermopolis Shale & 145 & $104.4-102$ & & & & 70 & 30 & & \\
\hline Cloverly Fm. & 285 & $134-104.4$ & & & 50 & 50 & & & \\
\hline Triassic and Jurassic rocks & 1,594 & $248-144$ & & & 50 & 50 & & & \\
\hline Hiatus & 0 & $253-248$ & & & & & & & \\
\hline Phosphoria/Park City Fm. & 230 & $278-253$ & & & & 60 & & 40 & \\
\hline Heat flow $44 \mathrm{~mW} / \mathrm{m}^{2}$ & \multicolumn{9}{|c|}{ Thermal gradient $1.18^{\circ} \mathrm{F} / 100$ feet } \\
\hline \multicolumn{10}{|c|}{ Amoco BN 1} \\
\hline Erosion & & $10-0$ & & 4,500 & & & & & \\
\hline Post-Paleocene rocks & 0 & $55-10$ & 4,500 & & 30 & 70 & & & \\
\hline Fort Union Fm. & 9,030 & $65.4-55$ & & & 70 & 30 & & & \\
\hline Lance Fm. & 1,290 & $69.4-65.4$ & & & 30 & 70 & & & \\
\hline Meeteetse Fm. & 980 & $72-69.4$ & & & 30 & 70 & & & \\
\hline Mesaverde Fm. (Teapot Ss. Mbr.) & 50 & $73-72$ & & & 100 & & & & \\
\hline Hiatus & 0 & $78-73$ & & & & & & & \\
\hline Mesaverde Fm. & 1,155 & $83-78$ & & & 40 & 60 & & & \\
\hline Cody Shale & 1,810 & $88.5-83$ & & & 20 & 80 & & & \\
\hline Frontier Fm. & 395 & $97.2-88.5$ & & & 40 & 60 & & & \\
\hline Mowry Shale & 600 & $99-97.2$ & & & & 100 & & & \\
\hline
\end{tabular}

Heat flow $51 \mathrm{~mW} / \mathrm{m}^{2}$

Thermal gradient $1.35^{\circ} \mathrm{F} / 100$ feet 
Table 2. Data used to generate burial history curves for eight locations, Bighorn Basin, Wyoming and Montana.-Continued

[Models only include stratigraphic units from the base of the Phosphoria Formation regardless of whether the well was drilled to deeper units. Mbr., Member; Fm., Formation; Ss., Sandstone; ft, feet; Ma, mega-annum; \%, percent; ss, sandstone; sh, shale; 1s, limestone; slst, siltstone; dolo, dolomite. Heat flow and thermal gradient used to calibrate model are given for each location. $\mathrm{mW} / \mathrm{m}^{2}$, milliWatts per square meter; ${ }^{\circ} \mathrm{F}$, degrees Fahrenheit]

\begin{tabular}{|c|c|c|c|c|c|c|c|c|c|}
\hline \multirow{2}{*}{$\begin{array}{l}\text { System/Series, Unit, } \\
\text { or Event }\end{array}$} & \multirow{2}{*}{$\begin{array}{c}\text { Present } \\
\text { thickness } \\
\text { (ft) }\end{array}$} & \multirow{2}{*}{$\begin{array}{l}\text { Age range } \\
(\mathrm{Ma})\end{array}$} & \multirow{2}{*}{$\begin{array}{c}\text { Deposited, } \\
\quad \text { later } \\
\text { eroded (ft) }\end{array}$} & \multirow{2}{*}{$\begin{array}{c}\text { Amount of } \\
\text { erosion } \\
\text { (ft) }\end{array}$} & \multicolumn{5}{|c|}{ Generalized lithology } \\
\hline & & & & & $\%$ ss & $\%$ sh & $\%$ slst & \%dolo & $\%$ coal \\
\hline \multicolumn{10}{|c|}{ Santa Fe Tatman } \\
\hline Erosion & & $10-0$ & & 6,000 & & & & & \\
\hline Post-middle Eocene rocks & 0 & $52-10$ & 6,000 & & 50 & 50 & & & \\
\hline Fort Union Fm. & 5,480 & $65.4-55$ & & & 50 & 50 & & & \\
\hline Lance Fm. & 1,350 & $69.4-65.4$ & & & 70 & 30 & & & \\
\hline Meeteetse Fm. & 785 & $72-69.4$ & & & 30 & 70 & & & \\
\hline Mesaverde Fm. (Teapot Ss. Mbr.) & 115 & $73-72$ & & & 100 & & & & \\
\hline Hiatus & 0 & $78-73$ & & & & & & & \\
\hline $\begin{array}{l}\text { Mesaverde Fm. (includes Claggett } \\
\text { Sh.and lower Mesaverde Fm.) }\end{array}$ & 1,100 & $82-78$ & & & 70 & 30 & & & \\
\hline Frontier Fm. & 440 & $97.2-89$ & & & 70 & 30 & & & \\
\hline Mowry Shale & 520 & $99-97.2$ & & & & 100 & & & \\
\hline Muddy Sandstone & 50 & $101-99$ & & & 100 & & & & \\
\hline Hiatus & 0 & $102-101$ & & & & & & & \\
\hline Thermopolis Shale & 160 & $104.4-102$ & & & & 100 & & & \\
\hline Cloverly Fm. & 258 & $134-104.4$ & & & 70 & 30 & & & \\
\hline Hiatus & 0 & $144-134$ & & & & & & & \\
\hline Jurassic rocks (part) & 37 & $150-144$ & & & 50 & 50 & & & \\
\hline \multirow{2}{*}{\multicolumn{10}{|c|}{$\begin{array}{c}\text { Thermal gradient } 1.30^{\circ} \mathrm{F} / 100 \text { feet } \\
\text { McCulloch Peak }\end{array}$}} \\
\hline & & & & & & & & & \\
\hline Erosion & & $10-0$ & & 5,000 & & & & & \\
\hline Post-middle Eocene rocks & 0 & $51-10$ & 5,000 & & 50 & 50 & & & \\
\hline Willwood Fm. & 2,485 & $55-51$ & & & 30 & 70 & & & \\
\hline Fort Union Fm. & 6,105 & $65.4-55$ & & & 50 & 50 & & & \\
\hline Lance Fm. & 1,320 & $69.4-65.4$ & & & 50 & 50 & & & \\
\hline Mesaverde Fm. (Teapot Ss. Mbr.) & 210 & $73-72$ & & & 70 & 30 & & & \\
\hline Hiatus & 0 & $78-73$ & & & & & & & \\
\hline Mesaverde Fm. & 740 & $83-78$ & & & 50 & 50 & & & \\
\hline Cody Shale & 2,115 & $88.5-83$ & & & 20 & 80 & & & \\
\hline Frontier Fm. & 535 & $97.2-88.5$ & & & 50 & 50 & & & \\
\hline Mowry Shale & 614 & $99-97.2$ & & & & 100 & & & \\
\hline Muddy Sandstone & 46 & $101-99$ & & & 100 & & & & \\
\hline Hiatus & 0 & $102-101$ & & & & & & & \\
\hline Cloverly Fm. & 186 & $134-104.4$ & & & 30 & 70 & & & \\
\hline
\end{tabular}


Table 2. Data used to generate burial history curves for eight locations, Bighorn Basin, Wyoming and Montana.—Continued

[Models only include stratigraphic units from the base of the Phosphoria Formation regardless of whether the well was drilled to deeper units. Mbr., Member; Fm., Formation; Ss., Sandstone; ft, feet; Ma, mega-annum; \%, percent; ss, sandstone; sh, shale; 1s, limestone; slst, siltstone; dolo, dolomite. Heat flow and thermal gradient used to calibrate model are given for each location. $\mathrm{mW} / \mathrm{m}^{2}$, milliWatts per square meter; ${ }^{\circ} \mathrm{F}$, degrees Fahrenheit]

\begin{tabular}{|c|c|c|c|c|c|c|c|c|c|}
\hline \multirow{2}{*}{$\begin{array}{c}\text { System/Series, Unit, } \\
\text { or Event }\end{array}$} & \multirow{2}{*}{$\begin{array}{l}\text { Present } \\
\text { thickness } \\
\text { (ft) }\end{array}$} & \multirow{2}{*}{$\begin{array}{l}\text { Age range } \\
(\mathrm{Ma})\end{array}$} & \multirow{2}{*}{$\begin{array}{l}\text { Deposited, } \\
\text { later } \\
\text { eroded (ft) }\end{array}$} & \multirow{2}{*}{$\begin{array}{l}\text { Amount of } \\
\text { erosion } \\
\text { (ft) }\end{array}$} & \multicolumn{5}{|c|}{ Generalized lithology } \\
\hline & & & & & $\%$ ss & $\%$ sh & $\%$ slst & \%dolo & $\%$ coal \\
\hline \multicolumn{10}{|c|}{ Dobie Creek } \\
\hline Erosion & & $10-0$ & & 6,500 & & & & & \\
\hline Post-middle Eocene rocks & 0 & $52-10$ & 6,500 & & 50 & 50 & & & \\
\hline Willwood Fm. & 2,315 & $55-52$ & & & 50 & 50 & & & \\
\hline Fort Union Fm. & 2,585 & $65.4-55$ & & & 50 & 50 & & & \\
\hline Lance Fm. & 865 & $69.4-65.4$ & & & 70 & 30 & & & \\
\hline $\begin{array}{l}\text { Meeteetse Fm. (includes Lewis } \\
\text { Sh.) }\end{array}$ & 555 & $72-69.4$ & & & 30 & 70 & & & \\
\hline Mesaverde Fm. (Teapot Ss. Mbr.) & 90 & $73-72$ & & & 100 & & & & \\
\hline Hiatus & 0 & $78-73$ & & & & & & & \\
\hline Mesaverde Fm. & 530 & $82-78$ & & & 70 & 30 & & & \\
\hline Cody Shale & 2,785 & $89-82$ & & & & 100 & & & \\
\hline Frontier Fm. & 445 & $97.2-89$ & & & 70 & 30 & & & \\
\hline Mowry Shale & 470 & $99-97.2$ & & & & 100 & & & \\
\hline Muddy Sandstone & 60 & $101-99$ & & & 100 & & & & \\
\hline Thermopolis Shale & 105 & $104.4-102$ & & & & 100 & & & \\
\hline \multirow{2}{*}{\multicolumn{10}{|c|}{$\begin{array}{c}\text { Thermal gradient } 1.49^{\circ} \mathrm{F} / 100 \text { feet } \\
\text { Doctor Ditch }\end{array}$}} \\
\hline & & & & & & & & & \\
\hline Erosion & & $10-0$ & & 4,500 & & & & & \\
\hline Post-Paleocene rocks & 0 & $55-10$ & 4,500 & & 30 & 70 & & & \\
\hline Fort Union Fm. & 5,410 & $65.4-55$ & & & 50 & 50 & & & \\
\hline Lance Fm. & 910 & $69.4-65.4$ & & & 30 & 70 & & & \\
\hline $\begin{array}{l}\text { Meeteetse Fm. (includes } \\
\text { Bearpaw Sh.) }\end{array}$ & 1,080 & $72-69.4$ & & & 50 & 50 & & & \\
\hline Mesaverde Fm. (Teapot Ss. Mbr.) & 30 & $73-72$ & & & 100 & & & & \\
\hline Hiatus & 0 & $78-73$ & & & & & & & \\
\hline Mesaverde Fm. & 850 & $83-78$ & & & 50 & 50 & & & \\
\hline Frontier Fm. & 580 & $97.2-88.5$ & & & 30 & 70 & & & \\
\hline Mowry Shale & 470 & $99-97.2$ & & & & 100 & & & \\
\hline Hiatus & 0 & $102-99$ & & & & & & & \\
\hline Thermopolis Shale & 320 & $104.4-102$ & & & 30 & 70 & & & \\
\hline Cloverly Fm. & 243 & $134-104.4$ & & & 70 & 30 & & & \\
\hline Hiatus & 0 & $144-134$ & & & & & & & \\
\hline Triassic and Jurassic rocks & 1,347 & $248-144$ & & & 34 & 33 & 33 & & \\
\hline Hiatus & 0 & $253-248$ & & & & & & & \\
\hline Phosphoria/Park City Fm. & 60 & $278-253$ & & & 50 & & & 50 & \\
\hline Heat flow $51 \mathrm{~mW} / \mathrm{m}^{2}$ & & ermal gradient & $1.37^{\circ} \mathrm{F} / 100 \mathrm{fee}$ & & & & & & \\
\hline
\end{tabular}


A
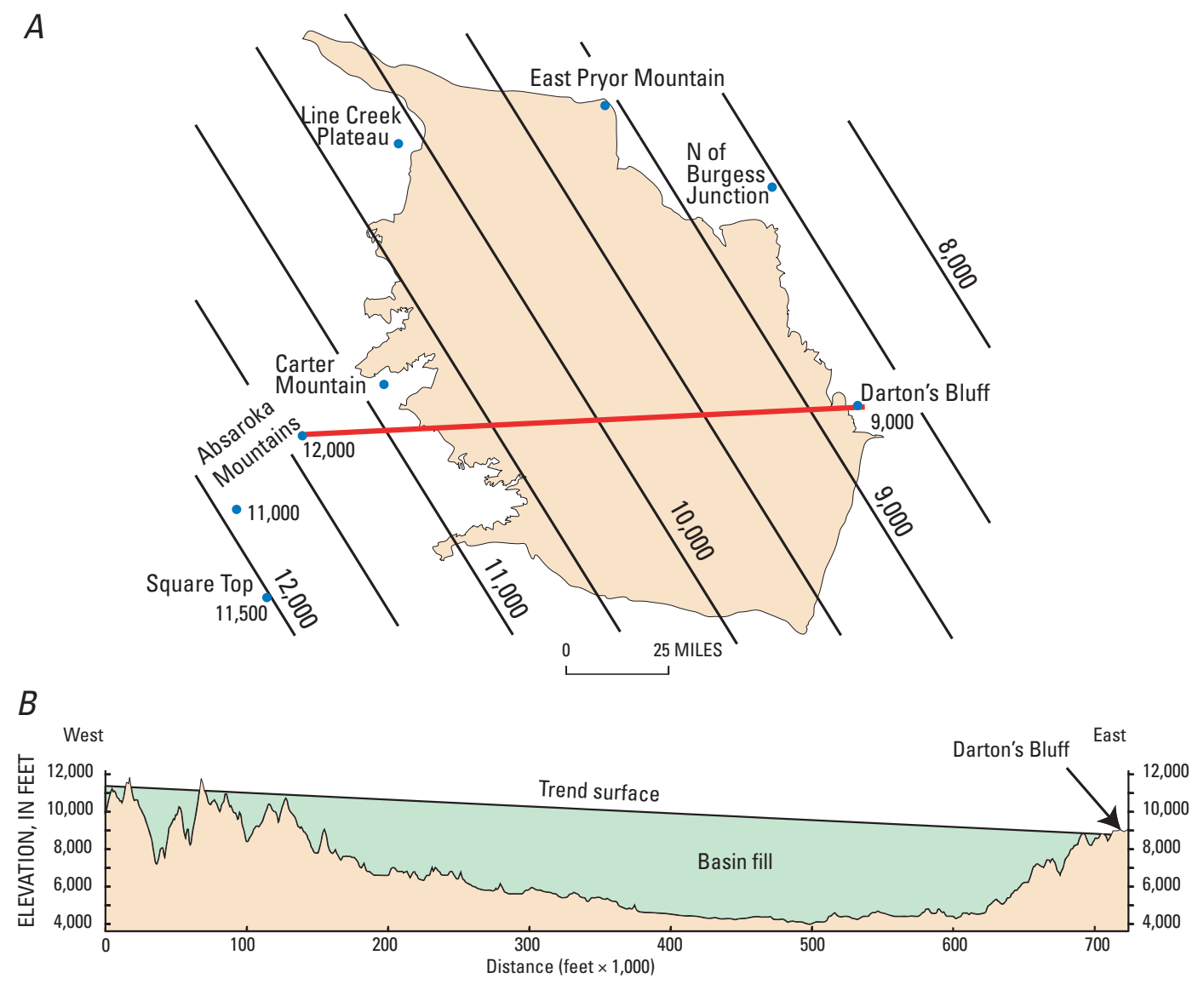

C

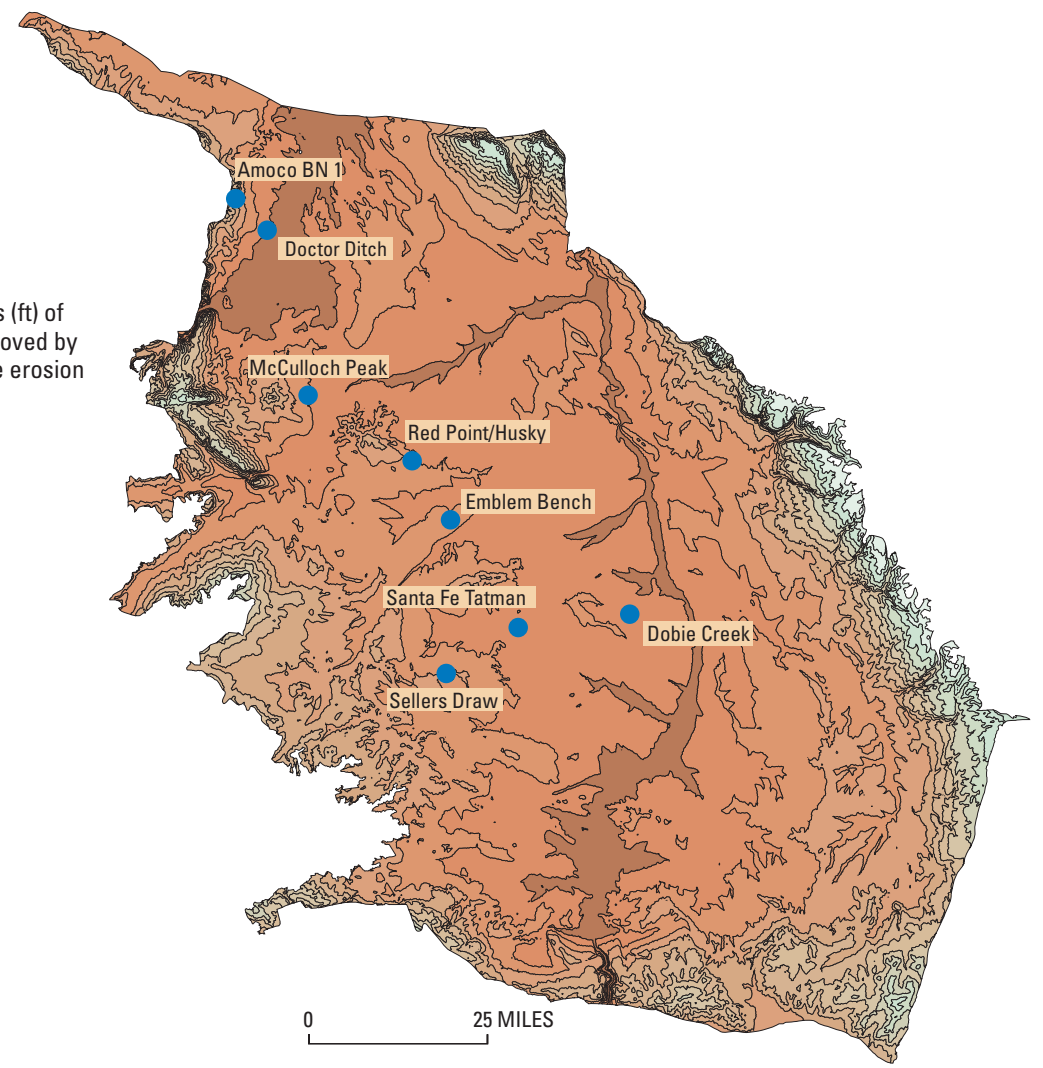

Figure 3. Maps and cross section showing method used to estimate post-middle Eocene deposition and erosion in the Bighorn Basin, Wyoming and Montana. $A$, trend surface using elevations of erosion surfaces described in Hagen and Surdam (1984) and Roberts and others (2007) and locality of Miocene vertebrates at Darton's Bluff. $B$, cross section showing estimated basin fill. $C$, isopach map of estimated post-middle Eocene erosion. 
Big Horn Mountains (McKenna and Love, 1972). The general eastward slope of the surface is consistent with interpretations of drainage patterns during the Oligocene (Lillegraven and Ostresh, 1988). Subtracting the grid of the modern topography (generated from a Digital Elevation Model) from this trend surface grid resulted in an isopach map of estimated eroded thickness of post-Paleocene to post-middle Eocene rocks (fig. 3C), which was then used as a guide for estimating thickness of erosion across the basin. The actual values applied in the modeling were determined by matching a calculated $\mathrm{R}_{\mathrm{o}}$ profile at each location with the measured data by using a combination of input parameters as described below.

Modeling results indicate that the amount of post-early Eocene deposition (from about 50 to $10 \mathrm{Ma}$ ) that was subsequently eroded (from $10 \mathrm{Ma}$ to the present) at the eight burial history locations is estimated to range from $4,500 \mathrm{ft}$ in the northern part of the basin to $6,500 \mathrm{ft}$ in the central part (fig. $3 C$ ). These erosion estimates are consistent with those reported by McMillan and others (2006), who used a similar method to estimate basin fill, but whose area of study included the entire Rocky Mountain orogenic plateau. In a summary of Cenozoic erosional events in the Bighorn Basin, Bown (1980) reported that between the early Miocene and the present day, more than $7,800 \mathrm{ft}$ of rock was removed by erosion from the Absaroka area and more than 5,000 feet from the eastern Bighorn Basin. Nuccio and Finn (1998) assumed a uniform gradient between an area in the Absaroka Range and Darton's Bluff and estimated the thickness of Tertiary rocks stripped from the central part of the Bighorn Basin to be about 4,900 ft.

\section{Methods-Thermal History}

For each of the eight burial history locations, bottomhole temperatures, temperatures from drill-stem tests, vitrinite reflectance $\left(\mathrm{R}_{\mathrm{o}}\right)$ data, and assumed average paleosurface temperatures were used to calibrate thermal models. The temperature data were from records on log headers of the individual wells used in modeling. The bottom-hole temperatures were corrected according to Waples and others (2004). $\mathrm{R}_{\mathrm{o}}$ data are from Nuccio and Finn (1998) and Finn and Pawlewicz (2007). The paleosurface temperature data from the beginning of the Late Cretaceous (100 Ma) to the present for all of the burial history locations were taken from those reported by Barker (2000) for the neighboring Wind River Basin to the south, except that, on the basis of annual surface temperature near Worland, Wyoming, in the Bighorn Basin, a present-day temperature of $7^{\circ} \mathrm{C}\left(44.5^{\circ} \mathrm{F}\right)$ was used. For the surface temperature history before $100 \mathrm{Ma}$, we used a constant paleosurface temperature of $20^{\circ} \mathrm{C}\left(68^{\circ} \mathrm{F}\right)$ from the beginning of deposition to $144 \mathrm{Ma}$ and gradually decreased the temperature to $17^{\circ} \mathrm{C}$ $\left(63^{\circ} \mathrm{F}\right)$ at $100 \mathrm{Ma}$ based loosely on a module that is included with the PetroMod1D ${ }^{\circledR}$ software that calculates paleosurface temperature through time at chosen latitudes (Wrygala, 1989).
Heat flow value, which is an input parameter for the PetroMod1D ${ }^{\circledR}$ program, is used for the burial history reconstructions (table 2). A present-day heat flow at the base of the stratigraphic column at each modeled location was determined within the PetroMod1D ${ }^{\circledR}$ program by calibrating thermal histories using the measured downhole temperatures and the present-day and assumed paleosurface temperatures. Heat flow values used at the modeled well locations range from 44 to 55 milliWatts per square meter $\left(\mathrm{mW} / \mathrm{m}^{2}\right)$, which is in agreement with the range of values documented by Decker and others (1980) for eastern Wyoming $\left(25\right.$ to $67 \mathrm{~mW} / \mathrm{m}^{2}$ ). Assuming our estimated burial depths and amounts of erosion to be geologically correct, using a constant heat flow through time resulted in an acceptable match between calculated and measured $\mathrm{R}_{\mathrm{o}}$ values, as determined by EASY\% $\mathrm{R}_{\mathrm{o}}$ (Sweeney and Burnham, 1990).

\section{Methods-Petroleum Generation History}

Timing of petroleum generation was determined for the seven source rocks at the eight burial history locations, and timing for the gas generation from the cracking of Phosphoria oil in Park City reservoirs was determined for two of the locations. The source rocks are either gas-prone or predominantly gas-prone, with the possibility of also being oil-prone as a result of variations in organic facies (for example, in the Thermopolis and Mowry Shales).

\section{Gas-Prone Source Rocks}

The extent of gas generation in source rocks with TypeIII kerogen can be equated to $\mathrm{R}_{\mathrm{o}}$ levels because it is measured on the macerals that generate the gas. Based on discussions in Roberts and others $(2004,2007)$, we used the values of 0.5 percent $\mathrm{R}_{\mathrm{o}}$ for the start of gas generation, 0.8 percent $\mathrm{R}_{\mathrm{o}}$ for peak generation, and 2.0 percent $\mathrm{R}$ for the end of gas generation from Type-III kerogen. Accordingly, EASY\% $\mathrm{R}_{\mathrm{o}}$ was used to model gas generation from gas-prone source rocks at these values. Gas generation discussed in this report refers only to thermogenic gas and not to biogenic gas.

\section{Oil-Prone Source Rocks}

Thermopolis and Mowry Shales in the Bighorn Basin consist of some Type-II kerogen (Burtner and Warner, 1984; Hagen and Surdam, 1984; unpublished RockEval data). Although they are predominantly gas-prone, they are potential oil-prone source rocks. Low-sulfur oils in Cretaceous reservoirs have been attributed to these two source rocks (Paul Lillis, oral commun., 2007). Oil generation from Type-II kerogen in these source rocks was modeled at the relevant burial history locations with hydrous pyrolysis kinetic 
parameters from Lewan and Ruble (2002) as discussed by Roberts and others (2004). The activation energy ( $\left.\mathrm{E}_{\mathrm{a}}\right)$ is 52.16 kilocalories per mole with a frequency factor $\left(\mathrm{A}_{\mathrm{o}}\right)$ of $5.707 \times$ $10^{26}$ million years. Source rock oil-generation kinetic parameters from hydrous pyrolysis experiments, combined with burial history and thermal maturity, determine the timing of the generation of expelled oil because expulsion is considered a consequence of generation (Momper, 1978; Lewan, 1997; Lewan and Ruble, 2002).

Although gas is generated during oil generation from oil-prone kerogen, this type of gas generation was not modeled; however, cracking of generated oil to gas was modeled. Hydrothermal-pyrolysis kinetic parameters used to determine the timing of gas generation from oil cracking are from Tsuzuki and others (1999; $\mathrm{C}_{15+}$ saturates). The activation energy $\left(\mathrm{E}_{\mathrm{a}}\right)$ is 76 kilocalories per mole with a frequency factor $\left(\mathrm{A}_{\mathrm{o}}\right)$ of $3.419 \times 10^{33}$ million years.

Phosphoria oil in the Bighorn Basin is thought to have migrated eastward from the Idaho-Wyoming thrust belt and accumulated in upper Paleozoic and lower Mesozoic reservoirs (Sheldon, 1967; Stone, 1967). Within the boundary of the Bighorn Basin, the Phosphoria Formation is thin and only locally rich in organic carbon (Claypool and others, 1978; Maughan, 1984; and Hiatt, 1997). For this reason we do not present modeling results of the timing of oil generation from Phosphoria source rocks but present only the timing of cracking of Phosphoria-sourced oil pooled in reservoirs of the Permian Park City Formation.

Each set of kinetic parameters previously described has its own transformation ratios that express the extent of oil generation from Type-II kerogen and oil cracking to gas. The transformation ratios are the decimal fraction of reaction completed (that is, $0.00=$ no reaction; $1.00=$ completed reaction) as determined by their kinetic parameters for the various source rocks at the burial history locations. Oil generation and oil cracking to gas are defined in this study by transformation ratios between 0.01 and 0.99 . Immature source rocks and uncracked oils have transformation ratios less than 0.01 , and source rocks and crude oils that have completed both oil generation and the cracking of oil to gas have transformation ratios greater than 0.99 . Peak oil generation and peak oil cracking to gas are defined at a transformation ratio of 0.50 when the maximum rate of reaction is reached. Because the kinetics for oil generation and for oil cracking are different, a transformation ratio of 0.50 for oil generation occurs at a lower thermal maturity than a transformation ratio of 0.50 for oil cracking.

\section{Results-Burial History}

Table 3 lists information on the present depth, calculated maximum depth of burial, and calculated temperatures at maximum depth for the source-rock intervals and for the Phosphoria/Park City Formation from the burial history reconstructions. Based on Nuccio and Finn (1998) and McMillan and others (2006), the time of maximum burial for all stratigraphic units at the modeled locations was placed at $10 \mathrm{Ma}$ (late-middle Miocene). Figure 4 presents the burial history curves from $120 \mathrm{Ma}$ (late Early Cretaceous) to the present; the burial history prior to $120 \mathrm{Ma}$ is not shown because it is comparatively consistent from location to location across the basin, indicating fairly constant and relatively slow subsidence/sedimentation rates within a stable tectonic setting. The onset of the Laramide orogeny in the Late Cretaceous triggered the changes in sedimentation rates and created depocenters at different areas of the Bighorn Basin at different times. Following is a brief description of the burial history at each location shown in figure 1: three in the deepest parts of the basin (Emblem Bench, Red Point/Husky, and Sellers Draw); three at intermediate depths (Amoco BN 1, Santa Fe Tatman, and McCulloch Peak); and two at relatively shallow locations (Dobie Creek and Doctor Ditch).

\section{Emblem Bench, Red Point/Husky, and Sellers Draw}

The Emblem Bench, Red Point/Husky, and Sellers Draw locations are all on the gently dipping flanks of the relatively deep part of the Bighorn Basin trough and represent the greatest depth to which the source rocks were buried (fig. 1, fig. 4A, table 3). From $278 \mathrm{Ma}$ to about $89 \mathrm{Ma}$, subsidence/ sedimentation rates appear to have been fairly constant and relatively slow. The rate of deposition increased substantially between 89 and about $52 \mathrm{Ma}$, resulting in a total of between about 17,000 and 18,600 ft (table 2) of section represented by this period of time. A brief episode of nondeposition occurred between 78 and $73 \mathrm{Ma}$, and, in the last 10 million years, an estimated $5,000 \mathrm{ft}$ of rock was removed by erosion from this part of the basin.

\section{Amoco BN 1}

The burial history reconstruction at Amoco BN 1, located in a small subbasin in the northern part of the Bighorn Basin (fig. 1), represents an intermediate depth to which source rocks were buried (table 3, fig. 4B). Between $88.5 \mathrm{Ma}$ and about $83 \mathrm{Ma}$, only about $1,800 \mathrm{ft}$ of Cody Shale was deposited there, whereas to the south and east the Cody thickens to as much as 2,400 $\mathrm{ft}$ (as at Sellers Draw). A big difference in the burial history at the Amoco BN 1 locality, as compared with other locations, is that during Paleocene Fort Union time, almost $2,000 \mathrm{ft}$ more sediment was deposited $(9,000 \mathrm{ft})$ than in the deep part of the basin $(7,000 \mathrm{ft})$ and almost $6,500 \mathrm{ft}$ more than at the Dobie Creek location $(2,500 \mathrm{ft})$ in the east-central part of the basin. After maximum burial from the addition of postPaleocene sediments, uplift and erosion caused the removal of an estimated 4,500 ft of section in the modeled area. 
Table 3. Present-day depth, calculated maximum depth of burial, and calculated temperature at maximum depth of burial for base of source rock intervals and for Phosphoria/Park City Formation from burial history reconstructions, Bighorn Basin, Wyoming and Montana.

$[\mathrm{ND}=$ no data. Depth values are in feet. Temperature values are degrees Fahrenheit. Fm., Formation; Sh, Shale ]

\begin{tabular}{|c|c|c|c|c|c|c|c|c|}
\hline \multirow{2}{*}{$\begin{array}{l}\text { Burial history } \\
\text { location }\end{array}$} & \multicolumn{8}{|c|}{ Source rock } \\
\hline & $\begin{array}{c}\text { Phosphoria } \\
\text { Fm. }\end{array}$ & $\begin{array}{c}\text { Thermopolis } \\
\text { Sh. }\end{array}$ & $\begin{array}{l}\text { Mowry } \\
\text { Shale }\end{array}$ & $\begin{array}{c}\text { Frontier } \\
\text { Fm. }\end{array}$ & $\begin{array}{l}\text { Cody } \\
\text { Shale }\end{array}$ & $\begin{array}{c}\text { Mesaverde } \\
\text { Fm. }\end{array}$ & $\begin{array}{l}\text { Meeteetse } \\
\text { Fm. }\end{array}$ & $\begin{array}{c}\text { Fort Union } \\
\text { Fm. }\end{array}$ \\
\hline \multicolumn{9}{|l|}{ Emblem Bench } \\
\hline Present-day depth & ND & 18,233 & 18,050 & 17,500 & 16,960 & 14,830 & 13,690 & 11,120 \\
\hline Maximum depth & ND & 23,250 & 23,030 & 22,530 & 21,940 & 19,810 & 18,690 & 16,110 \\
\hline Present-day depth & ND & 18,930 & 18,710 & 18,170 & 17,700 & 15,450 & 14,500 & 11,950 \\
\hline Maximum depth & ND & 23,730 & 23,530 & 23,010 & 22,520 & 20,270 & 19,310 & 16,780 \\
\hline Temperature & ND & 358 & 355 & 348 & 341 & 308 & 297 & 264 \\
\hline \multicolumn{9}{|l|}{ Sellers Draw } \\
\hline \multicolumn{9}{|l|}{ Amoco BN 1} \\
\hline Present-day depth & ND & ND & 15,310 & 14,710 & 14,315 & 12,505 & 11,300 & 9,030 \\
\hline Maximum depth & ND & ND & 19,780 & 19,180 & 18,750 & 16,980 & 15,730 & 13,490 \\
\hline Temperature & ND & ND & 337 & 327 & 321 & 294 & 276 & 243 \\
\hline \multicolumn{9}{|l|}{ Santa Fe Tatman } \\
\hline Present-day depth & ND & 15,850 & 15,640 & 15,120 & 14,680 & 12,300 & 11,085 & 8,950 \\
\hline Maximum depth & ND & 21,580 & 21,640 & 21,130 & 20,710 & 18,280 & 17,080 & 14,950 \\
\hline Temperature & ND & 345 & 342 & 334 & 328 & 291 & 275 & 247 \\
\hline \multicolumn{9}{|l|}{ McCulloch Peak } \\
\hline Temperature & ND & 311 & 313 & 306 & 299 & 251 & 241 & 220 \\
\hline \multicolumn{9}{|l|}{ Doctor Ditch } \\
\hline Present-day depth & 13,020 & 11,370 & 11,050 & 10,580 & 10,000 & 8,280 & 7,400 & 5,410 \\
\hline Maximum depth & 17,530 & 15,860 & 15,530 & 15,070 & 14,490 & 12,760 & 11,890 & 9,880 \\
\hline Temperature & 305 & 281 & 276 & 267 & 260 & 234 & 222 & 194 \\
\hline
\end{tabular}



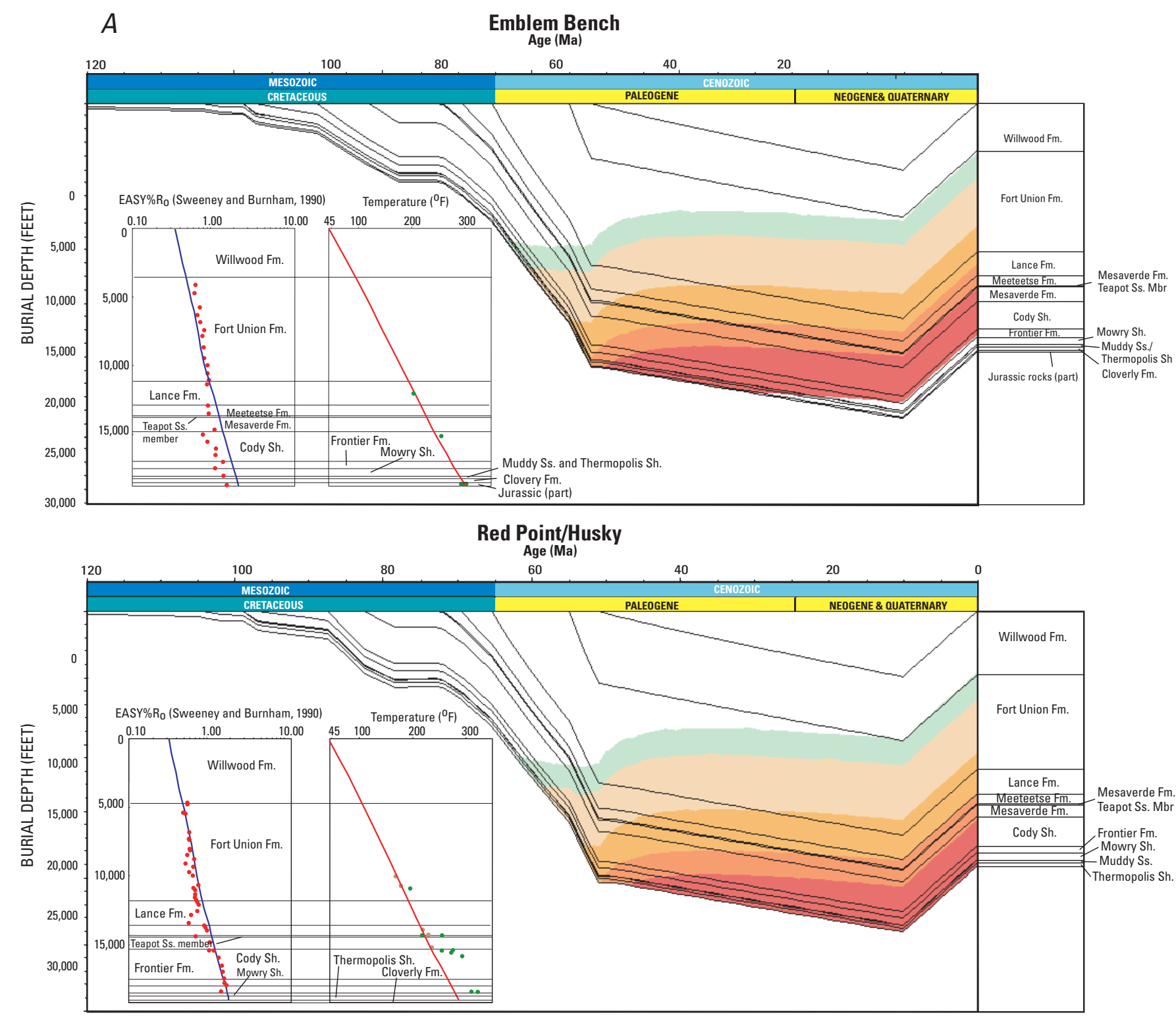

\section{EXPLANATION}

\begin{tabular}{|c|c|}
\hline$\% \mathrm{R}_{0}$ ra & nge (calc \\
\hline 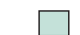 & $0.50-0.60$ \\
\hline$\square$ & $0.60-0.80$ \\
\hline & $0.80-1.10$ \\
\hline & $1.10-1.35$ \\
\hline$\square$ & $1.35-2.00$ \\
\hline
\end{tabular}

Figure 4. Burial history curves at eight locations in the Bighorn Basin, Wyoming and Montana. $A$, locations where source rocks were most deeply buried. $B$, locations where source rocks were buried to intermediate depths, $C$, locations where source rocks were buried to shallowest depths. Burial history model locations are shown in figure 1. Data used to construct the curves are presented in table 2. Ages are given in millions of years before present (Ma, mega-annum). Abbreviations: Fm., Formation; Mbr., Member; Ss., Sandstone; Sh., Shale. Calibration of models, using vitrinite reflectance $\left(R_{0}\right)$ and down-hole temperature, is shown with each associated burial history curve. Red dots on the left graph are measured $\mathrm{R}_{0}$ values. Green dots on the right graph are down-hole temperatures (corrected, in degrees Fahrenheit); brown dots are temperatures from drill-stem tests. Colors on the burial history curves represent calculated $R_{0}$ with burial depth and time (see color key). 


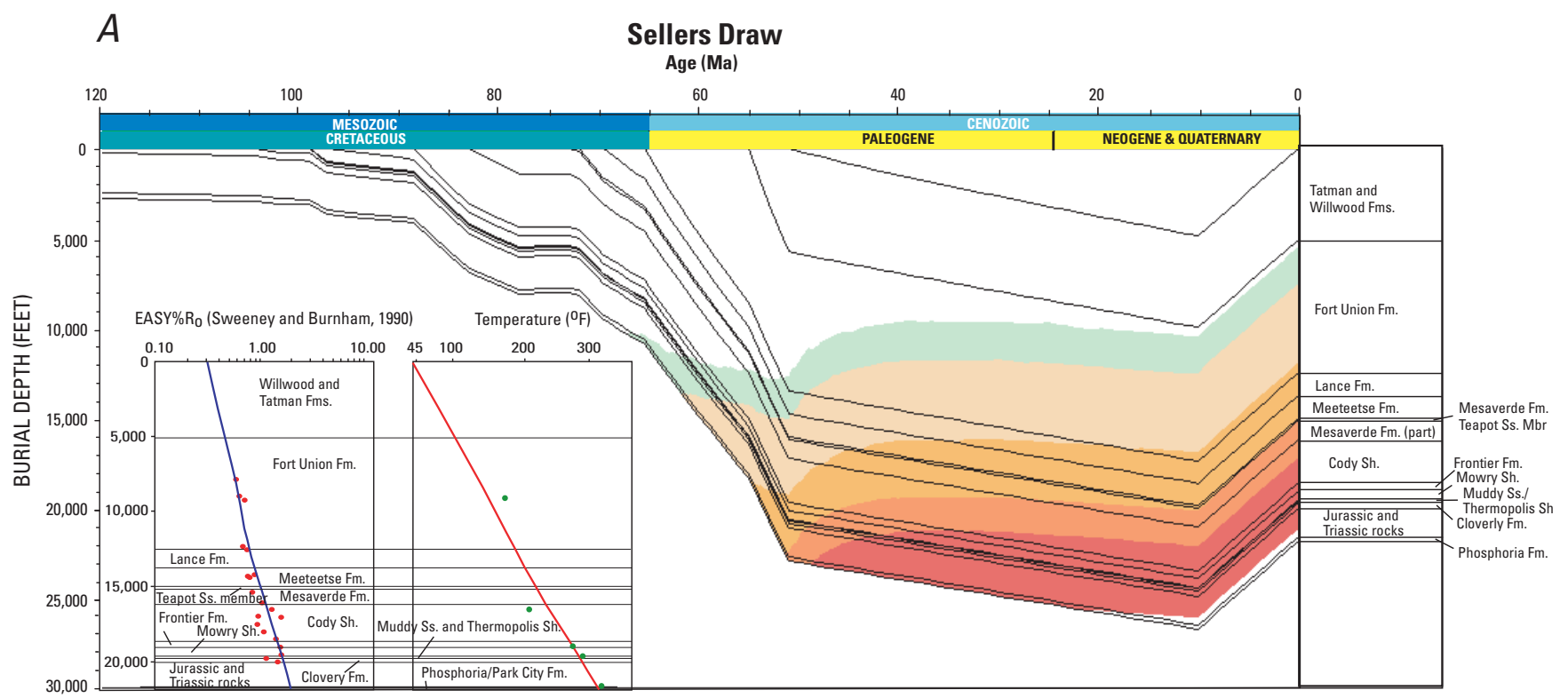

\section{EXPLANATION}

$\% \mathrm{R}_{0}$ range (calculated)

\begin{tabular}{|c|}
\hline $0.50-0.60$ \\
\hline $0.60-0.80$ \\
\hline $0.80-1.10$ \\
\hline $1.10-1.35$ \\
\hline $1.35-2.0$ \\
\hline
\end{tabular}

Figure 4. Burial history curves at eight locations in the Bighorn Basin, Wyoming and Montana. $A$, locations where source rocks were most deeply buried. $B$, locations where source rocks were buried to intermediate depths, $C$, locations where source rocks were buried to shallowest depths. Burial history model locations are shown in figure 1. Data used to construct the curves are presented in table 2. Ages are given in millions of years before present (Ma, mega-annum). Abbreviations: Fm., Formation; Mbr., Member; Ss., Sandstone; Sh., Shale. Calibration of models, using vitrinite reflectance $\left(R_{0}\right)$ and down-hole temperature, is shown with each associated burial history curve. Red dots on the left graph are measured $\mathrm{R}_{0}$ values. Green dots on the right graph are down-hole temperatures (corrected, in degrees Fahrenheit); brown dots are temperatures from drill-stem tests. Colors on the burial history curves represent calculated $\mathrm{R}_{0}$ with burial depth and time (see color key).-Continued 

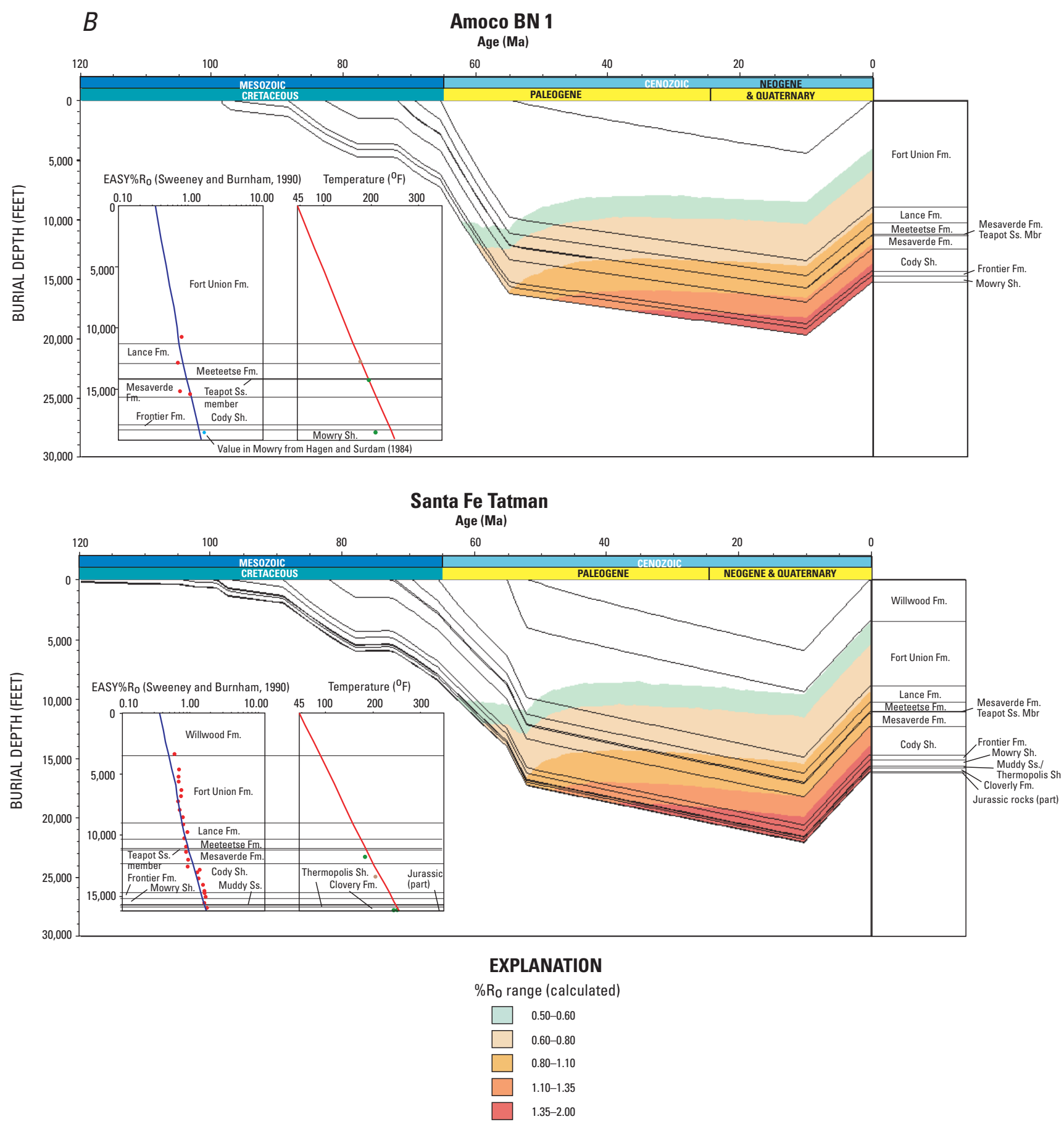

Figure 4. Burial history curves at eight locations in the Bighorn Basin, Wyoming and Montana. $A$, locations where source rocks were most deeply buried. $B$, locations where source rocks were buried to intermediate depths, $C$, locations where source rocks were buried to shallowest depths. Burial history model locations are shown in figure 1. Data used to construct the curves are presented in table 2. Ages are given in millions of years before present (Ma, mega-annum). Abbreviations: Fm., Formation; Mbr., Member; Ss., Sandstone; Sh., Shale. Calibration of models, using vitrinite reflectance $\left(R_{0}\right)$ and down-hole temperature, is shown with each associated burial history curve. Red dots on the left graph are measured $\mathrm{R}_{0}$ values. Green dots on the right graph are down-hole temperatures (corrected, in degrees Fahrenheit); brown dots are temperatures from drill-stem tests. Colors on the burial history curves represent calculated $R_{0}$ with burial depth and time (see color key).-Continued 


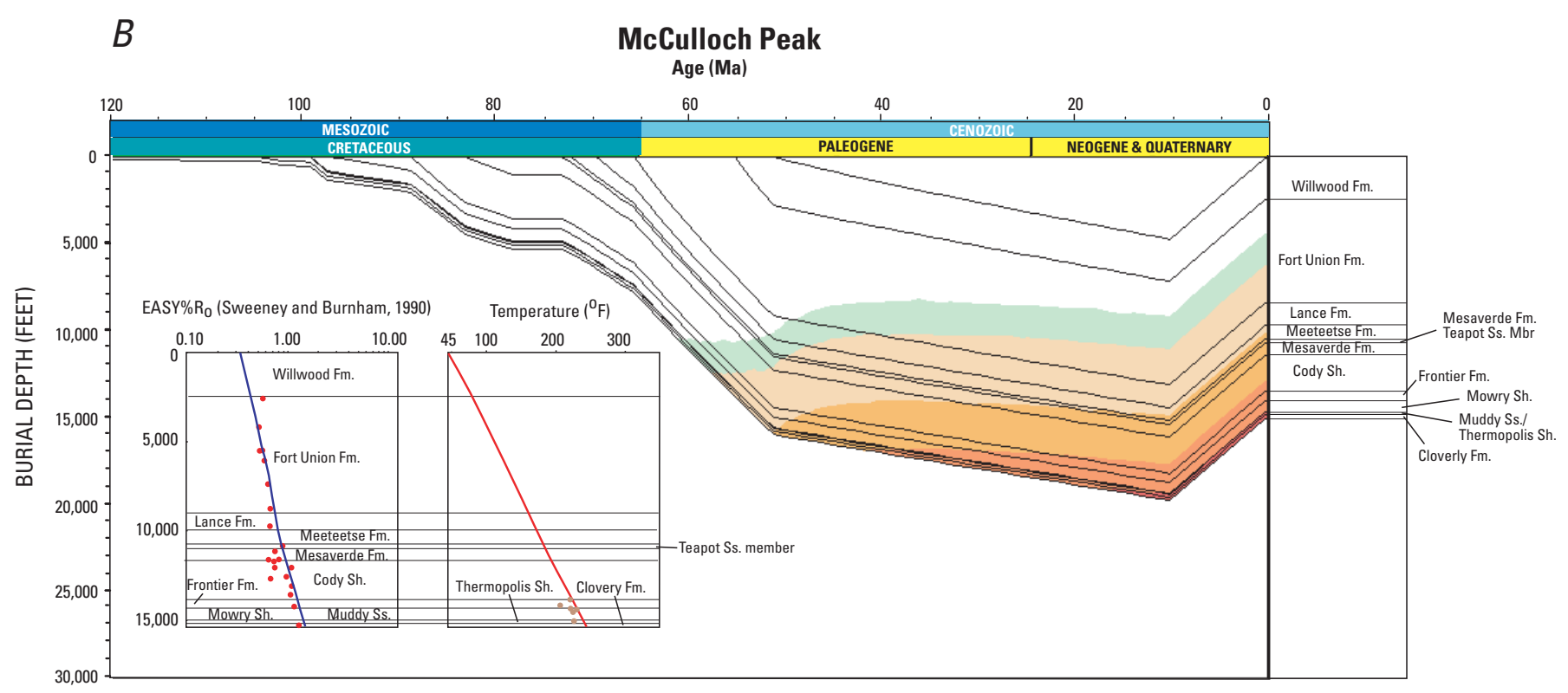

EXPLANATION

$\% \mathrm{R}_{0}$ range (calculated)

\begin{tabular}{ll}
\hline & $0.50-0.60$ \\
$\square$ & $0.60-0.80$ \\
$\square$ & $0.80-1.10$ \\
$\square$ & $1.10-1.35$ \\
$\square$ & $1.35-2.00$
\end{tabular}

Figure 4. Burial history curves at eight locations in the Bighorn Basin, Wyoming and Montana. $A$, locations where source rocks were most deeply buried. $B$, locations where source rocks were buried to intermediate depths, $C$, locations where source rocks were buried to shallowest depths. Burial history model locations are shown in figure 1. Data used to construct the curves are presented in table 2. Ages are given in millions of years before present (Ma, mega-annum). Abbreviations: Fm., Formation; Mbr., Member; Ss., Sandstone; Sh., Shale. Calibration of models, using vitrinite reflectance $\left(R_{0}\right)$ and down-hole temperature, is shown with each associated burial history curve. Red dots on the left graph are measured $R_{0}$ values. Green dots on the right graph are down-hole temperatures (corrected, in degrees Fahrenheit); brown dots are temperatures from drill-stem tests. Colors on the burial history curves represent calculated $\mathrm{R}_{0}$ with burial depth and time (see color key).-Continued 

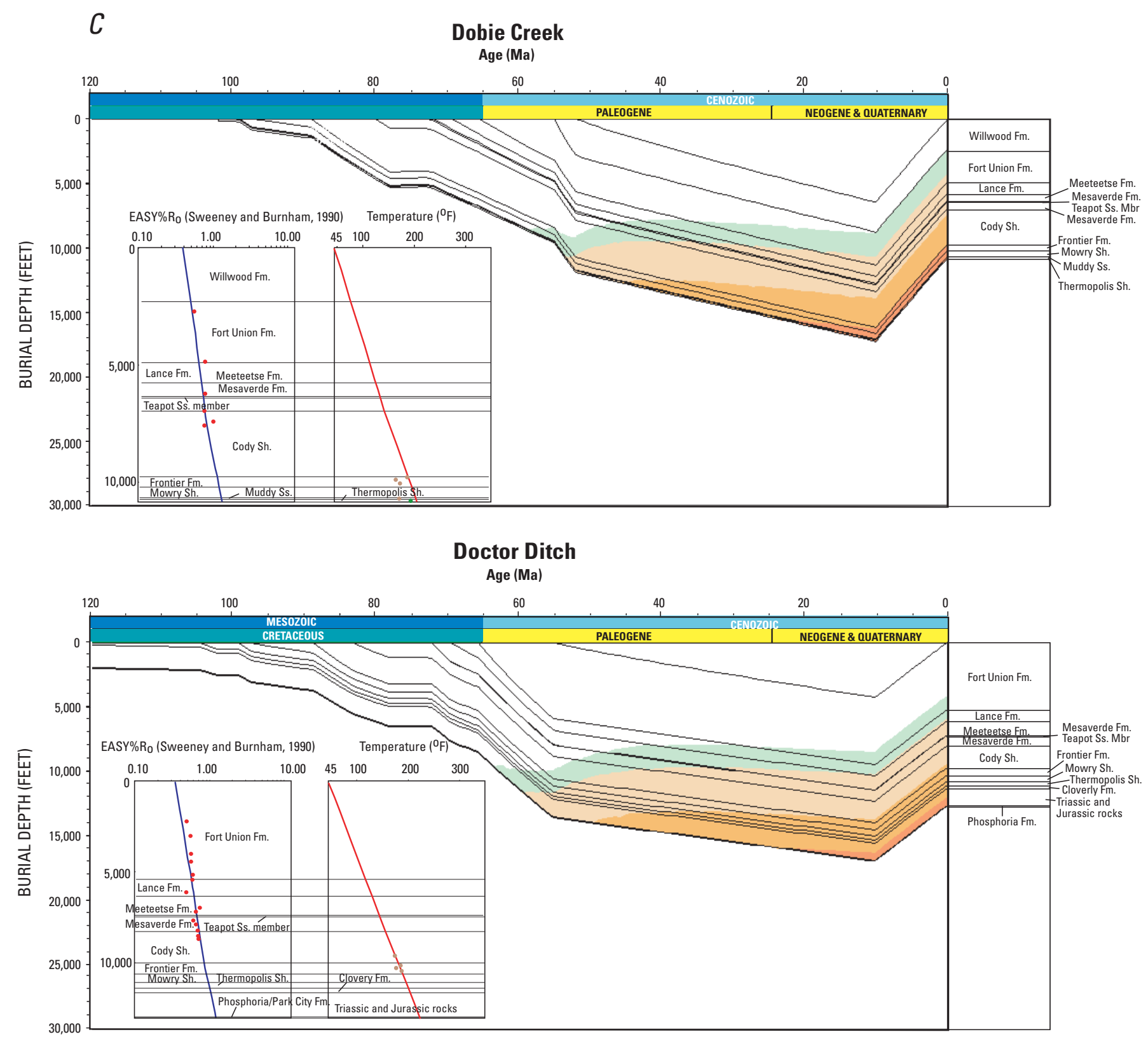

\section{EXPLANATION}

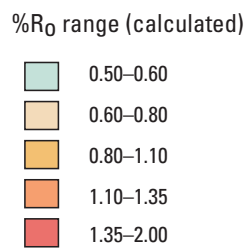

Figure 4. Burial history curves at eight locations in the Bighorn Basin, Wyoming and Montana. $A$, locations where source rocks were most deeply buried. $B$, locations where source rocks were buried to intermediate depths, $C$, locations where source rocks were buried to shallowest depths. Burial history model locations are shown in figure 1. Data used to construct the curves are presented in table 2. Ages are given in millions of years before present (Ma, mega-annum). Abbreviations: Fm., Formation; Mbr., Member; Ss., Sandstone; Sh., Shale. Calibration of models, using vitrinite reflectance $\left(R_{0}\right)$ and down-hole temperature, is shown with each associated burial history curve. Red dots on the left graph are measured $\mathrm{R}_{0}$ values. Green dots on the right graph are down-hole temperatures (corrected, in degrees Fahrenheit); brown dots are temperatures from drill-stem tests. Colors on the burial history curves represent calculated $\mathrm{R}_{0}$ with burial depth and time (see color key).-Continued 


\section{Santa Fe Tatman}

The Santa Fe Tatman location is situated on the gently west-dipping flank of the Bighorn Basin trough (fig. 1). The burial history here is most like that at the Emblem Bench location (fig. 4A); however, sedimentation/subsidence rates began to decrease in the Santa Fe Tatman area at about the end of deposition of the Meeteetse Formation, resulting in an interval of Lance and Fort Union rocks that is about 2,500 ft thinner than at the Emblem Bench location. An estimated 6,000 ft of post-middle Eocene sediments was deposited and then eroded at this location. Cretaceous source rocks at Santa Fe Tatman were buried to depths that were 2,000 to 3,000 ft shallower than those at locations in the deep part of the basin but were about 4,000 ft deeper than at the Doctor Ditch location in the northern part of the basin (table 3 ).

\section{McCulloch Peak}

The McCulloch Peak location is on a subtle anticlinal structure in the west-central part of the Bighorn Basin trough (fig. 1). The burial history here (fig. 4B) also closely resembles that at Emblem Bench, except that the rate of sediment accumulation was not as rapid during deposition of the Lance through the Fort Union Formations, resulting in a lesser thickness of about 2,000 ft for that interval. We estimate that the thickness of post-middle Eocene deposition and subsequent erosion was about 5,000 ft at the McCulloch Peak location.

\section{Dobie Creek}

The burial history at Dobie Creek (fig. 4C), located on a northwest-trending anticline in the southeastern part of the Bighorn Basin (fig. 1), is virtually the same as that to the west at the Santa Fe Tatman location until about the end of Mesaverde deposition. At that time the sedimentation/subsidence rates began to decrease, and about one-half the thickness of Meeteetse through Willwood sediments were deposited as compared to the Santa Fe Tatman location. An additional 6,500 ft of post-middle Eocene sediments is estimated to have been deposited at Dobie Creek before the final erosional event.

\section{Doctor Ditch}

The Doctor Ditch location lies on a small anticlinal structure less than $10 \mathrm{mi}$ updip to the southeast of the Amoco BN 1 location (fig. 1). This location, along with the Dobie Creek location, represents one of the two areas where source rocks were buried to the least depths (fig. $4 C$, table 3 ). The burial history here closely resembles that of the Amoco BN 1 location, except that almost 4,000 ft more Paleocene sediments were deposited at Amoco BN 1. This difference in thickness in such a short distance can probably be attributed to the growth of the anticline (where Doctor Ditch is located) during the
Paleocene and the consequential thinning of the Fort Union Formation across the structure. As in the area of the Amoco BN 1 location, we estimate that about 4,500 ft of post-Paleocene rocks was eroded from this area.

\section{Results-Maturation History}

Maturation history is calibrated based on matching as closely as possible, the measured and calculated $R_{0}$ for each burial history location. Figure 4 shows selected ranges of $R_{0}$ superimposed on the burial history curves. The range of 0.5 to $0.8 \% \mathrm{R}_{\mathrm{o}}$ represents the prescribed start-to-peak gas generation from humic coals. The $\mathrm{R}_{\mathrm{o}}$ values of 1.10 and 1.35 percent were added for information purposes only and represent intermediate maturities between peak $\left(0.8 \% \mathrm{R}_{\mathrm{o}}\right)$ and end $\left(2.0 \% \mathrm{R}_{\mathrm{o}}\right)$ of gas generation. All of the Cretaceous and Paleocene source rocks are considered gas-prone (mostly composed of TypeIII kerogen) or possibly oil-prone (Thermopolis and Mowry Shales), so $\mathrm{R}_{\mathrm{o}}$ can be used to estimate extent of gas generation. Table 4 summarizes the time (Ma) that the base of the source rock intervals attained the $\% \mathrm{R}_{\mathrm{o}}$ values of $0.5,0.8$, and 2.0 , and the depths of the source rock at the specific $\mathrm{R}_{0}$ maturity level.

\section{Results-Petroleum Generation History}

The timing and extent of petroleum generation from the prescribed source rocks at the eight burial history locations are listed in tables 4 and 5 and summarized in figures 5 and 6 . With the exception of the Dobie Creek and Doctor Ditch locations, the burial history curves represent relatively deep parts of the Bighorn Basin (fig. 1). As a result, the other six curves represent the earliest timing and greatest extent of petroleum generation in the identified source-rock intervals. Updip from these locations, the time at which petroleum generation occurred would be later and the extent of petroleum generation would be less.

A vertical dashed line at $10 \mathrm{Ma}$ on each of figures 5 and 6 represents the onset of regional uplift, erosion, and subsequent cooling at all of the burial history locations. Based on kinetic and burial history modeling, rates of gas generation, oil generation, and oil cracking to gas were significantly reduced after that time, with negligible generation during the last 10 m.y.

As expected, the most extensive petroleum generation occurred at the locations where source rocks were most deeply buried, which include the Emblem Bench, Red Point/ Husky, and Sellers Draw locations (figs. 5, 6). The Amoco BN 1, Santa Fe Tatman, and McCulloch Peak locations, which represent intermediate burial depths, had moderately extensive petroleum generation, and the shallowest burial depths at the Dobie Creek and Doctor Ditch locations resulted in the least extensive petroleum generation. Burial depths at the Sellers 
Table 4. Timing of gas generation for Type-III source rocks at burial history locations, Bighorn Basin, Wyoming and Montana.

[Age values are in Ma. Depth values are calculated depth of burial at which vitrinite reflectance (\%Ro) value was reached (in feet). Double hyphen indicates horizon did not attain \%Ro value]

\begin{tabular}{|c|c|c|c|c|c|c|c|c|c|c|c|c|c|c|}
\hline \multirow{3}{*}{$\begin{array}{c}\text { Burial } \\
\text { history } \\
\text { location }\end{array}$} & \multicolumn{14}{|c|}{ Source rock } \\
\hline & \multicolumn{2}{|c|}{$\begin{array}{c}\text { Thermopolis } \\
\text { Shale }\end{array}$} & \multicolumn{2}{|c|}{$\begin{array}{c}\text { Mowry } \\
\text { Shale }\end{array}$} & \multicolumn{2}{|c|}{$\begin{array}{l}\text { Frontier } \\
\text { Formation }\end{array}$} & \multicolumn{2}{|c|}{$\begin{array}{l}\text { Cody } \\
\text { Shale }\end{array}$} & \multicolumn{2}{|c|}{$\begin{array}{c}\text { Mesaverde } \\
\text { Formation }\end{array}$} & \multicolumn{2}{|c|}{$\begin{array}{l}\text { Meeteetse } \\
\text { Formation }\end{array}$} & \multicolumn{2}{|c|}{$\begin{array}{l}\text { Fort Union } \\
\text { Formation }\end{array}$} \\
\hline & Age & Depth & Age & Depth & Age & Depth & Age & Depth & Age & Depth & Age & Depth & Age & Depth \\
\hline \multicolumn{15}{|l|}{ Emblem Bench } \\
\hline $0.5 \% \mathrm{R}_{\mathrm{o}}-$ Start & 63 & 10,240 & 63 & 10,270 & 62 & 10,340 & 61 & 10,510 & 58 & 10,740 & 56 & 10,710 & 53 & 10,710 \\
\hline $0.8 \% \mathrm{R}_{\mathrm{o}}$ - Peak & 55 & 16,120 & 55 & 16,150 & 54 & 16,360 & 54 & 16,360 & 51 & 16,000 & 49 & 14,940 & 35 & 13,690 \\
\hline $2.0 \% \mathrm{R}_{\mathrm{o}}$ - End & 26 & 21,770 & 22 & 21,880 & 12 & 22,330 & -- & & -- & & -- & & -- & \\
\hline \multicolumn{15}{|c|}{ Red Point Unit/Husky } \\
\hline $0.5 \% \mathrm{R}_{\mathrm{o}}-\mathrm{Start}$ & 62 & 10,820 & 62 & 10,860 & 60 & 11,110 & 60 & 11,190 & 56 & 11,570 & 54 & 11,570 & 52 & 11,530 \\
\hline $0.8 \% \mathrm{R}_{\mathrm{o}}$ - Peak & 53 & 17,500 & 53 & 17,560 & 53 & 17,580 & 52 & 17,580 & 49 & 16,690 & 48 & 15,870 & 31 & 14,910 \\
\hline $2.0 \% \mathrm{R}_{\mathrm{o}}$ - End & -- & & -- & & -- & & -- & & -- & & -- & & -- & \\
\hline \multicolumn{15}{|l|}{ Sellers Draw } \\
\hline $0.5 \% \mathrm{R}_{\mathrm{o}}-$ Start & 62 & 11,570 & 61 & 11,760 & 60 & 11,810 & 59 & 12,040 & 55 & 12,410 & 54 & 12,680 & 52 & 12,780 \\
\hline $0.8 \% \mathrm{R}_{\mathrm{o}}$ - Peak & 53 & 19,120 & 52 & 19,170 & 52 & 19,260 & 51 & 19,310 & 48 & 17,590 & 44 & 16,710 & 19 & 16,570 \\
\hline $2.0 \% \mathrm{R}_{\mathrm{o}}-$ End & -- & & -- & & -- & & -- & & -- & & -- & & -- & \\
\hline \multicolumn{15}{|l|}{ Amoco BN 1} \\
\hline $0.5 \% \mathrm{R}_{\mathrm{o}}-\mathrm{Start}$ & no data & & 63 & 10,110 & 62 & 10,300 & 61 & 10,240 & 58 & 10,690 & 57 & 10,620 & 54 & 10,040 \\
\hline $0.8 \% \mathrm{R}_{\mathrm{o}}$ - Peak & no data & & 55 & 16,090 & 54 & 15,770 & 54 & 15,390 & 47 & 14,030 & 39 & 13,520 & -- & \\
\hline $2.0 \% \mathrm{R}_{\mathrm{o}}$ - End & no data & & -- & & -- & & -- & & -- & & -- & & -- & \\
\hline \multicolumn{15}{|c|}{ Santa Fe Tatman } \\
\hline $0.5 \% \mathrm{R}_{\mathrm{o}}-$ Start & 62 & 10,030 & 61 & 10,190 & 60 & 10,220 & 59 & 10,280 & 54 & 10,930 & 53 & 10,960 & 51 & 10,157 \\
\hline $0.8 \% \mathrm{R}_{\mathrm{o}}$ - Peak & 53 & 16,490 & 52 & 16,520 & 52 & 16,370 & 51 & 15,990 & 42 & 14,570 & 32 & 14,570 & -- & \\
\hline $2.0 \% \mathrm{R}_{\mathrm{o}}-$ End & -- & & -- & & -- & & -- & & -- & & -- & & -- & \\
\hline \multicolumn{15}{|c|}{ McCulloch Peak } \\
\hline $0.5 \% \mathrm{R}_{\mathrm{o}}-$ Start & 61 & 10,570 & 60 & 10,520 & 59 & 10,560 & 58 & 10,650 & 54 & 10,600 & 53 & 10,430 & 49 & 9,400 \\
\hline $0.8 \% \mathrm{R}_{\mathrm{o}}$ - Peak & 51 & 15,820 & 51 & 15,600 & 49 & 15,170 & 48 & 14,740 & 31 & 14,270 & 15 & 14,740 & -- & \\
\hline $2.0 \% \mathrm{R}_{\mathrm{o}}-$ End & -- & & -- & & -- & & -- & & -- & & -- & & -- & \\
\hline \multicolumn{15}{|l|}{ Dobie Creek } \\
\hline $0.5 \% \mathrm{R}_{\mathrm{o}}-$ Start & 60 & 8,330 & 59 & 8,330 & 57 & 8,330 & 56 & 8,260 & 49 & 8,260 & 47 & 7,960 & 38 & 7,690 \\
\hline $0.8 \% \mathrm{R}_{\mathrm{o}}$ - Peak & 47 & 12,590 & 46 & 12,510 & 44 & 12,370 & 40 & 12,310 & -- & & -- & & -- & \\
\hline \multicolumn{15}{|l|}{ Doctor Ditch } \\
\hline $0.5 \% \mathrm{R}_{\mathrm{o}}-$ Start & 60 & 9,880 & 59 & 9,950 & 58 & 10,020 & 57 & 10,040 & 53 & 9,320 & 49 & 8,670 & 33 & 7,950 \\
\hline $0.8 \% \mathrm{R}_{\mathrm{o}}$ - Peak & 42 & 13,280 & 40 & 13,180 & 33 & 13,250 & 23 & 13,460 & -- & & -- & & -- & \\
\hline $2.0 \% \mathrm{R}_{0}-$ End & -- & & -- & & -- & & -- & & -- & & -- & & -- & \\
\hline
\end{tabular}


Table 5. Timing of oil generation for Type-Il source rocks and timing of oil cracking to gas, Bighorn Basin, Wyoming and Montana.

[Start, peak, and end of oil generation and of oil cracking to gas are represented by transformation ratios of $0.01,0.50$, and 0.99 , respectively, and are calculated at a horizon in the middle of the source-rock interval. Age values are Ma. Timing of Phosphoria oil cracking to gas was modeled for Park City reservoirs. Blank cell indicates source rock did not attain minimum transformation ratio.

Values in brackets are transformation ratios at the present time (0 Ma)]

\begin{tabular}{|c|c|c|c|c|c|c|}
\hline \multirow{2}{*}{$\begin{array}{c}\text { Source } \\
\text { rock }\end{array}$} & \multicolumn{3}{|c|}{ Oil generation } & \multicolumn{3}{|c|}{ Oil cracking to gas } \\
\hline & Start & Peak & End & Start & Peak & End \\
\hline \multicolumn{7}{|l|}{ Emblem Bench } \\
\hline Thermopolis Shale & 58 & 54 & 52 & 36 & & $0[0.11]$ \\
\hline Mowry Shale & 57 & 53 & 51 & 32 & & $0[0.07]$ \\
\hline \multicolumn{7}{|l|}{ Red Point/Husky } \\
\hline Thermopolis Shale & 56 & 52 & 50 & 16 & & $0[0.02]$ \\
\hline Mowry Shale & 55 & 52 & 49 & no gas & & \\
\hline \multicolumn{7}{|l|}{ Sellers Draw } \\
\hline Phosphoria/Park City Formation & & & & 37 & & $0[0.04]$ \\
\hline Thermopolis Shale & 56 & 51 & 48 & no gas & & \\
\hline Mowry Shale & 55 & 50 & 47 & no gas & & \\
\hline \multicolumn{7}{|l|}{ Amoco BN 1} \\
\hline Mowry Shale & 58 & 53 & 46 & no gas & & \\
\hline \multicolumn{7}{|l|}{ Santa Fe Tatman } \\
\hline Thermopolis Shale & 55 & 51 & 47 & no gas & & \\
\hline Mowry Shale & 54 & 50 & 44 & no gas & & \\
\hline \multicolumn{7}{|l|}{ McCulloch Peak } \\
\hline Thermopolis Shale & 55 & 48 & 38 & no gas & & \\
\hline Mowry Shale & 54 & 46 & 32 & no gas & & \\
\hline \multicolumn{7}{|l|}{ Dobie Creek } \\
\hline Thermopolis Shale & 52 & 40 & 26 & no gas & & \\
\hline Mowry Shale & 51 & 37 & 19 & no gas & & \\
\hline \multicolumn{7}{|l|}{ Doctor Ditch } \\
\hline Phosphoria/Park City Formation & & & & no gas & & \\
\hline Thermopolis Shale & 52 & 24 & $0[0.82]$ & no gas & & \\
\hline Mowry Shale & 50 & 16 & $0[0.64]$ & no gas & & \\
\hline
\end{tabular}




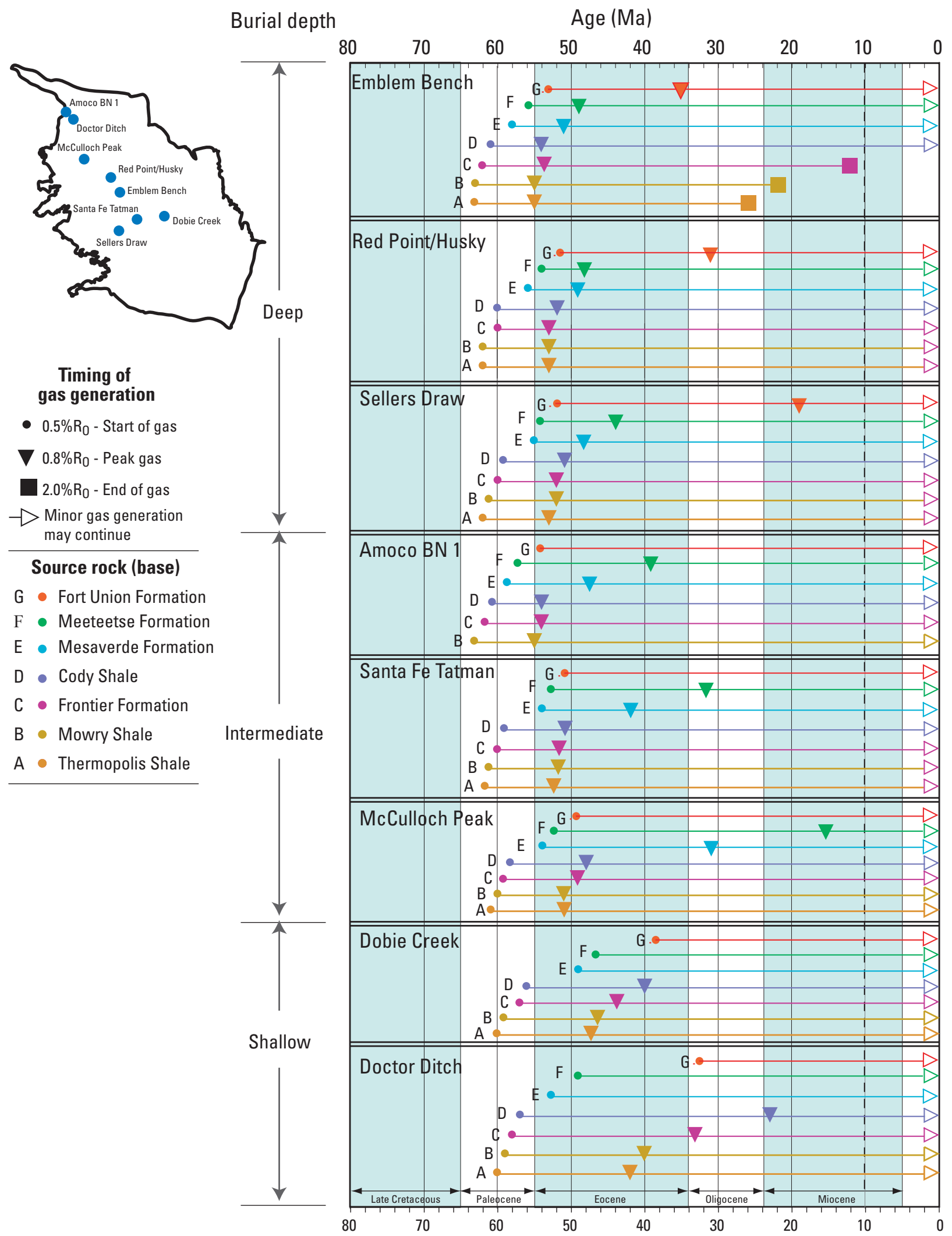

Figure 5. Timing of gas generation from Type-III source rocks for each source rock and burial history location in the Bighorn Basin, Wyoming and Montana. Vertical dashed line at $10 \mathrm{Ma}$ represents beginning of regional uplift, erosion, and subsequent cooling. If gas generation has not ended by present day based on the models, the rate of gas generation was significantly reduced with negligible generation during the last 10 million years. 

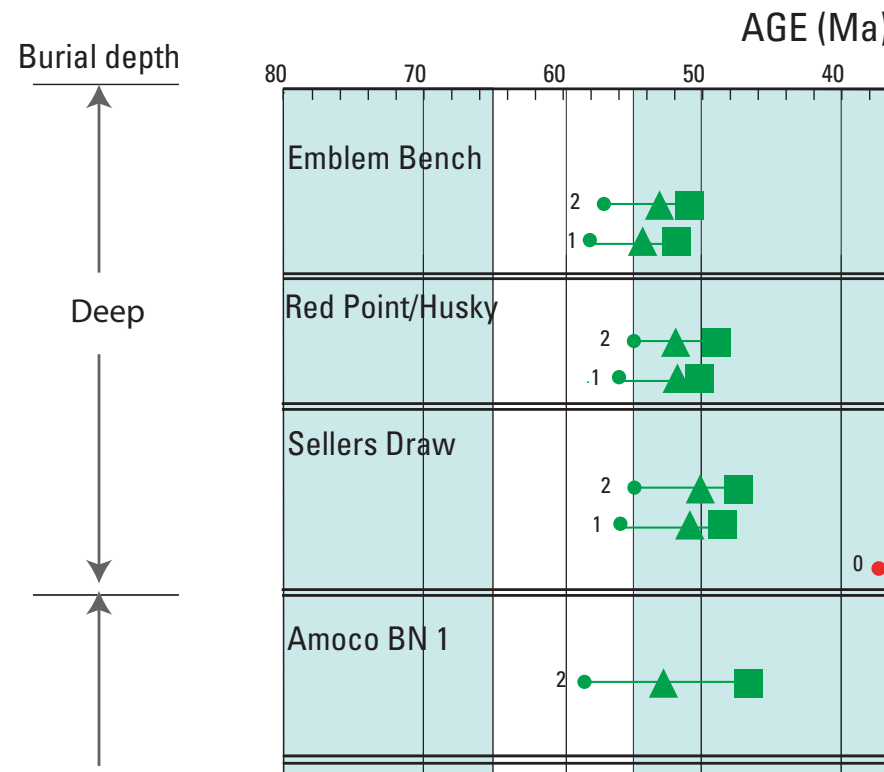
40 a)
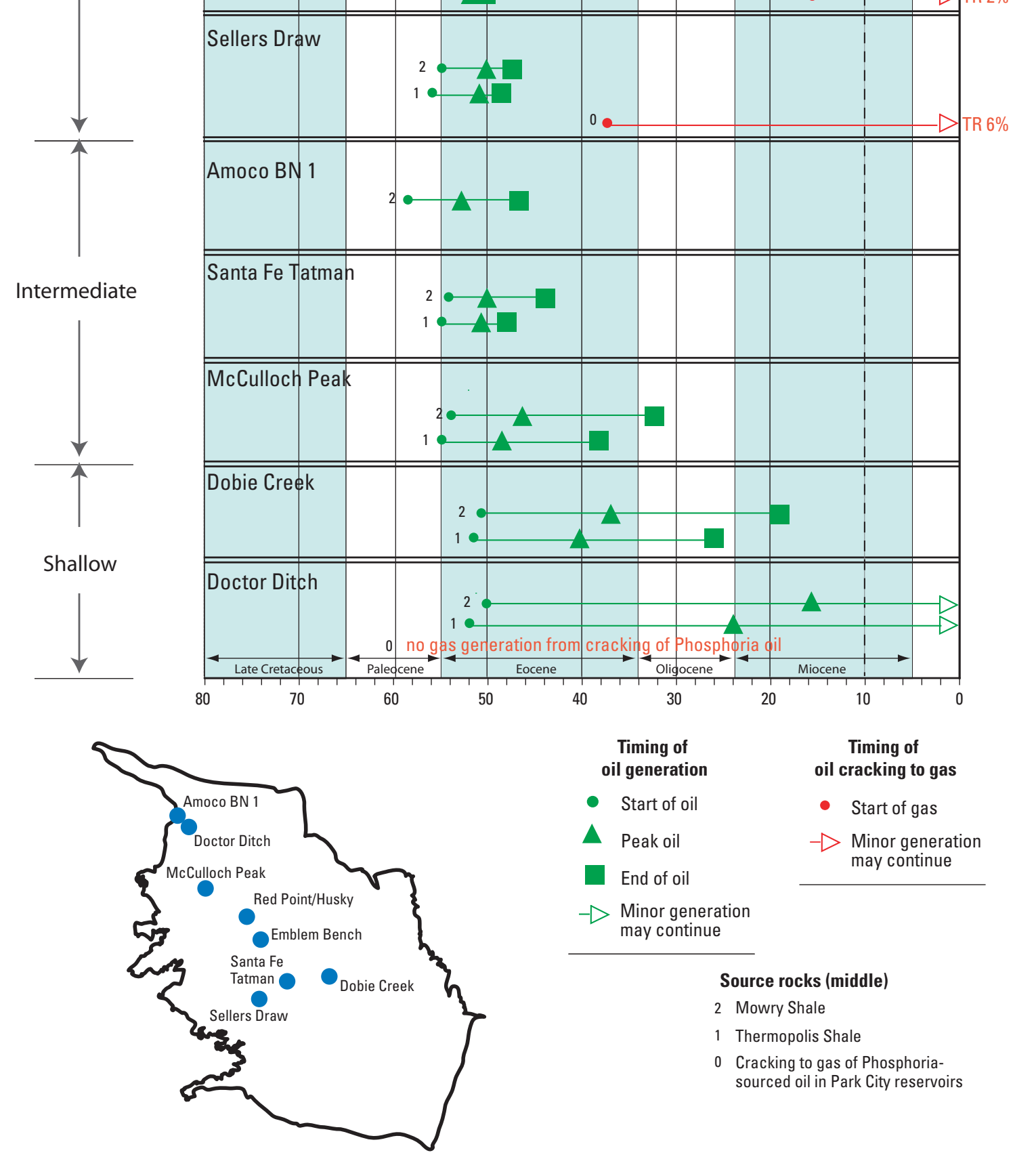

Figure 6. Timing of oil and gas generation from Type-II source rocks for each source rock and burial history location in the Bighorn Basin, Wyoming and Montana. Vertical dashed line at 10 Ma represents beginning of regional uplift, erosion, and subsequent cooling. If oil generation or oil cracking to gas has not ended by present day based on the models, the rate of these reactions was significantly reduced with negligible generation during the last 10 million years. TR, transformation ratio. 
Draw location in the deep part of the Bighorn Basin are slightly greater than at Emblem Bench and Red Point/Husky, but because of a lower thermal gradient (table 2), the timing of petroleum generation at Sellers Draw was slightly later and the extent of petroleum generation was less (figs. 5, 6).

\section{Gas Generation from Source Rocks}

The onset of gas generation from all the gas-prone source rocks buried the deepest $(16,000$ to $>24,000 \mathrm{ft})$, as well as those buried to intermediate depths (from about 13,500 to 20,000 ft) extended over a narrow range of only 12 m.y. starting at $63 \mathrm{Ma}$ for the Thermopolis Shale to $49 \mathrm{Ma}$ for the Fort Union Formation. At the two locations where source rocks were buried to the shallowest depths (from about 10,000 to $17,000 \mathrm{ft}$ ), the timing of onset of gas generation from Cretaceous source rocks is similar to that of the other locations; however, Fort Union source rocks did not start gas generation until much later, 38 to $33 \mathrm{Ma}$. The most complete gas generation in the Bighorn Basin occurred in the gas-prone source rocks in the deepest basin settings - at the Emblem Bench, Red Point/Husky, and Sellers Draw locations (fig. 5), where gas generation from the Cretaceous source rocks peaked from 55 to $44 \mathrm{Ma}$. Only at these deep basin locations did the source rocks of the Fort Union Formation reach peak generation. The results of timing of gas generation are generally consistent with those obtained by Nuccio and Finn (1998) for the Sellers Draw location.

At locations where gas-prone source rocks were buried to intermediate depths, gas generation from the Thermopolis stratigraphically upward through the Cody source rocks reached a peak at about the same time as source rocks at locations in the deep part of the basin; however, peak generation of gas from Mesaverde source rocks, occurred later (middle to late Eocene) than in the deep part of the basin. Thermal maturity of the Fort Union source rocks at these intermediate depths was not high enough to reach peak gas generation.

As expected at locations where gas-prone source rocks were buried to the shallowest depths, fewer source rocks reached the maturity level necessary to attain peak gas generation. Also, the time span from onset to peak gas generation is greater for those source rocks that ultimately did generate gas. Results of modeling indicate a similar timing for the start of gas generation from the shallower buried Thermopolis through the Cody source rocks as at locations where these source rocks were buried to intermediate depths. Peak generation, however, did not occur in Mesaverde and Meeteetse source rocks.

\section{Oil Generation from Source Rocks}

Timing of the start, peak, and end of oil generation (transformation ratios of $0.01,0.50$, and 0.99 , respectively) for Type-II source rocks was calculated at a horizon in the middle of the source-rock intervals. The results are given in table 5 and shown in figure 6 . The beginning of oil generation from the two oil-prone source rocks considered in this study extended over a narrow range of only 8 m.y. - starting at $58 \mathrm{Ma}$ for the Thermopolis and $50 \mathrm{Ma}$ for the Mowry -regardless of depth of burial or location.

Oil generation peaked between early and middle Eocene (54 - $46 \mathrm{Ma})$, at all locations for the Thermopolis and Mowry, except at the shallowest locations (Dobie Creek and Doctor Ditch) where peak oil generation for the Mowry occurred later (37 - 16 Ma). Similarly, oil generation ended for these source rocks at all locations except Dobie Creek by the early Miocene (19 Ma).

\section{Oil Cracking to Gas}

Timing of the start, peak, and end of oil cracking to gas (transformation ratios of $0.01,0.50$, and 0.99 , respectively) is given in table 5 and shown in figure 6 . These transformation ratios pertain to generated oils that are retained in their host source rock or in immediately adjacent reservoirs. In the case of generated Phosphoria oils that migrated from outside the basin, the transformation ratios pertain to oil that may have migrated long distances into the Park City Formation and immediately adjacent reservoirs.

It is apparent from the modeling that the gas generated from the cracking of oil does not contribute significantly to the overall gas potential of the Bighorn Basin. Figure 6 shows that the cracking of oil to gas took place only in the locations where source rocks were buried the deepest. For Phosphoriasourced oils, timing of the cracking could only be calculated for the Sellers Draw and Doctor Ditch locations because the other wells did not penetrate the Park City Formation. The cracking of Phosphoria oil at Sellers Draw began in the early Oligocene, but none took place at the Doctor Ditch location (table 5). It is certain, however, that Phosphoria oil did crack to gas at Emblem Bench and Red Point/Husky because oil from the younger, less deeply buried Cretaceous source rocks cracked to gas. Gas from cracking of Cretaceous oil started from the late Eocene to middle Miocene. It is important to note that the tranformation ratios at the present are all less than 0.10 , indicating that cracking only just started before uplift, erosion, and cooling essentially shut down petroleum generation.

\section{Summary}

Burial history, thermal maturity, and timing of petroleum generation were modeled for seven petroleum source-rock intervals at eight locations throughout the Bighorn Basin, as was the timing for the generation of gas from the cracking of Phosphoria oil in Park City Formation reservoirs at two locations. The results indicate that in areas where source rocks were buried the deepest (16,000 to $>24,000 \mathrm{ft}$ ), gas generation from Type-III source rocks started in the early Paleocene (about $63 \mathrm{Ma}$ for Cretaceous source rocks) to early Eocene 
(52 Ma for Fort Union Formation source rocks), reached peak by the middle Eocene (44 Ma for Cretaceous source rocks), and ended only at the Emblem Bench location by the late Miocene (12 Ma for Frontier Formation source rocks). The results are similar for source rocks buried at intermediate depths (from about 13,500 to 20,000 ft), except that Mesaverde and Meeteetse Formations did not reach peak generation until later in the Eocene to early Miocene (47 to $15 \mathrm{Ma}$ ) and Fort Union source rocks did not reach peak generation. Timing of gas generation from source rocks buried to shallowest depths (from about 10,000 to 17,000 ft), ranges from onset of gas from the middle Paleocene (60 Ma for the Thermopolis Shale) to early Oligocene (33 Ma for the Fort Union) and peak generation was reached only in the Thermopolis, Mowry Shale, Frontier Formation, and Cody Shale sources from middle Eocene (47 Ma) to early Miocene (23 Ma).

Modeling results indicate that in areas where oil-prone source rocks of the Thermopolis and Mowry Shales were buried the deepest, oil generation started and ended in a relatively narrow age range from late Paleocene to middle Eocene (58 to $47 \mathrm{Ma}$ ). Oil generation started and ended for these source rocks buried at intermediate depths, except the age range is greater, from late Paleocene to late Eocene (58 to $35 \mathrm{Ma}$ ). Timing of the onset of oil generation from source rocks buried to shallowest depths occurred in early Eocene (52 Ma), and ended only at Dobie Creek by early Miocene (19 Ma).

The gas generated from the cracking of oil does not contribute significantly to the overall gas potential of the Bighorn Basin, according to the models. Only in the locations where source rocks were buried the deepest did the the cracking of oil to gas take place. For Phosphoria-sourced oil at Sellers Draw, cracking began in the late Eocene (37 Ma) and probably occurred at about the same time in the other two deep locations. Gas from cracking of oil sourced from the Thermopolis and Mowry Shales started in the late Eocene to middle Miocene (37 to $16 \mathrm{Ma})$.

\section{References Cited}

Barker, C.E., 2000, A paleolatitude approach to assessing surface temperature history for use in burial heating models: International Journal of Coal Geology, v. 43, p. 121-135.

Bown, T.M., 1980, Summary of latest Cretaceous and Cenozoic sedimentary, tectonic, and erosional events, Bighorn Basin, Wyoming, in Gingerich, P.D., ed., Early Cenozoic paleontology and stratigraphy of the Bighorn Basin: Ann Arbor, University of Michigan Papers on Paleontology, no. 24 , p. 25-32.
Burtner, R.L., and Warner, M.A., 1984, Hydrocarbon generation in Lower Cretaceous Mowry and Skull Creek Shales of the Northern Rocky Mountain area, in Woodward, Jane, Meissner, F.F., and Clayton, J.L., eds., Hydrocarbon source rocks of the Greater Rocky Mountain Region: Rocky Mountain Association of Geologists, p. 449-467.

Claypool, G.E., Love, A.H., and Maughan, E.K., 1978, Organic geochemistry, incipient metamorphism and oil generation in Black Shale Members of the Phosphoria Formation, Western Interior United States: American Association of Petroleum Geologists Bulletin, v. 62, p. 98-120.

Decker, E.R., Baker, K.R., Bucher, G.J., and Heasler, H.P., 1980, Preliminary heat flow and radioactivity studies in Wyoming: Journal of Geophysical Research, v. 85, no. B1, p. 311-321.

Dynamic Graphics, Inc., 2005, EarthVision software: Dynamic Graphics, Inc., 1015 Atlantic Avenue, Alameda, California, accessed on 08/16/2007 at http://www.dgi.com.

Finn, T.M., and Pawlewicz, M.J., 2007, New vitrinite reflectance data for the Bighorn Basin, north-central Wyoming and south-central Montana: U.S. Geological Survey OpenFile Report 2007-1246, 9 p.

Green, G.N., and Drouillard, P.H., 1994, The digital geologic map of Wyoming in ARC/INFO format: U.S. Geological Survey Open-File Report 94-0425, 10 p.

Hagen, E.S., 1986, Hydrcarbon maturation in Laramide-style basins - Constraints from the northern Bighorn Basin, Wyoming and Montana: Laramie, Ph.D. dissertation, University of Wyoming, $215 \mathrm{p}$.

Hagen, E.S., and Surdam, R.C., 1984, Maturation history and thermal evolution of Cretaceous source rocks of the Bighorn Basin, Wyoming and Montana, in Woodward, Jane, Meissner, F.F., and Clayton, J.L., eds., Hydrocarbons source rocks of the greater Rocky Mountain Region: Denver, Colorado, Rocky Mountain Association of Geologists, p. 321-338.

Hiatt, E.E., 1997, A paleoceanographic model for oceanic upwelling in a Late Paleozoic epicontinental sea: a chemostratigraphic analysis of the Permian Phosphoria Formation: Boulder, University of Colorado, Ph.D. dissertation, $294 \mathrm{p}$.

IHS Energy Group, 2004, Petroleum Information/Dwights PetroROM well history data on CD-ROM: IHS Energy Group, 15 Inverness Way East, D205, Englewood, CO 80112.

Integrated Exploration Systems, 2005, PetroMod® Basin and Petroleum Systems Modeling Software: IES GmbH, Ritterstraße 23, D_52072 Aachen, Germany, accessed on 8/16/2007 at http://www.ies.de. 
Keefer, W.R., Finn, T.M., Johnson, R.C., and Keighin, C.W., 1998, Regional stratigraphy and correlation of Cretaceous and Paleocene rocks, Bighorn Basin, Wyoming and Montana, in Keefer, W.R., and Goolsby, J.E., eds., Cretaceous and lower Tertiary rocks of the Bighorn Basin, Wyoming and Montana: Wyoming Geological Association FortyNinth Guidebook, p. 1-30.

Lawton, T.F., 1994, Tectonic setting of Mesozoic sedimentary basins, Rocky Mountain Region, United States, in Caputo, M.V., Peterson, J.A., and Franczyk, K.J., eds., Mesozoic systems of the Rocky Mountain Region, USA, Rocky Mountain Section: SEPM (Society for Sedimentary Geology), Denver, Colorado, p. 1-25.

Lewan, M.D., 1997, Experiments on the role of water in petroleum formation: Geochimica et Cosmochimica Acta, v. 61, p. 3691-3723.

Lewan, M.D., and Ruble, T.E., 2002, Comparison of petroleum generation kinetics by isothermal hydrous and nonisothermal open-system pyrolysis: Organic Geochemistry, v. 33 , p. $1457-1475$.

Lillegraven, J.A, and Ostresh, L.M., Jr., 1988, Evolution of Wyoming's early Cenozoic topography and drainage patterns: National Geographic Research, v. 4, no. 3, p. 303-327.

Love, J.D., Christiansen, A.C., and Ver Ploeg, A.J., 1993, Stratigraphic chart showing Phanerozoic nomenclature for the state of Wyoming: Wyoming Geological Survey Map Series no. 41.

Maughan, E.K., 1984, Geological setting and some geochemistry of petroleum source rocks in the Permian Phosphoria Formation, in Woodward, Jane, Meissner, F.F., and Clayton, J.L., eds., Hydrocarbon source rocks of the Greater Rocky Mountain region: Rocky Mountain Association of Geologists, p. 281-294.

McKenna, M.C., and Love, J.D., 1972, High-level strata containing early Miocene mammals on the Bighorn Mountains, Wyoming: American Museum of Natural History, American Museum Novitates, no. 2490, 31 p.

McMillan, M.E., Heller, P.L., and Wing, S.L., 2006, History and causes of post-Laramide relief in the Rocky Mountain orogenic plateau: Geological Society of America Bulletin, v. 118 . no. $3 / 4$, p. 393-405.

Merewether, E.A., 1996, Stratigraphy and tectonic implications of Upper Cretaceous rocks in the Powder River Basin, northeastern Wyoming and southeastern Montana: U.S. Geological Survey Bulletin 1917-T, 92 p.
Merewether, E.A., Dolson, J.C., Hanson, W.B., Keefer, W.R., Law, B.E., and Mueller, R.E., 1997, Cretaceous stratigraphy in a northeast-trending transect, northern Utah to south-central South Dakota: U.S. Geological Survey Miscellaneous Investigations Series I-2609, 2 sheets.

Momper, J.A., 1978, Oil migration limitations suggested by geological and geochemical considerations, in Physical and chemical constraints on petroleum migration, Volume 1: American Association of Petroleum Geologists Continuing Education Course Note Series no. 8, p. B1-B60.

Nuccio, V.F., and Finn, T.M., 1998, Thermal maturity and petroleum generation history of Cretaceous and Tertiary source rocks, Bighorn Basin, Wyoming and Montana, in Keefer, W.R., and Goolsby, J.E., eds., Cretaceous and Lower Tertiary rocks of the Bighorn Basin, Wyoming and Montana: Wyoming Geological Association Forty-Ninth Guidebook, p. 211-231.

Palmer, A.R., and Geissman, John, comps., 1999, Geologic time scale, Product Code CTS004, Geological Society of America.

Raines, G.L., and Johnson, B.R., 1995, Digital representation of the Montana state geologic map-A contribution to the Interior Columbia River basin ecosystem management project: U.S. Geological Survey Open-file Report 95-691, 20 p.

Roberts, L.N.R., Lewan, M.D., and Finn, T.M., 2004, Timing of oil and gas generation of petroleum systems in the Southwestern Wyoming Province: The Mountain Geologist, v. 41 , no. 3 , p. 87-117.

Roberts, L.N.R., Lewan, M.D., and Finn, T.M., and Kirschbaum, M.A., 2007, Burial history, thermal maturity, and oil and gas generation history of petroleum systems in the Wind River Basin Province, central Wyoming, in Petroleum systems and geologic assessment of oil and gas in the Wind River Basin Province, Wyoming: U.S. Geological Survey Digital Data Series DDS-69-J, chap. 6, 33 p.

Ryder, R.T., 1987, Oil, gas, and coal resources of the McCullough Peaks Wilderness study area, Bighorn Basin, Wyoming: U.S. Geological Survey Open-File Report 87-646, 59 p.

Sheldon, R.P., 1967, Long distance migration of oil in Wyoming: The Mountain Geologist, v. 4, no. 2, p. 53-65.

Stone, D.S., 1967, Theory of Paleozoic oil and gas accumulation in Big Horn Basin, Wyoming: American Association of Petroleum Geologists Bulletin, v. 51, no. 10, p. 2056-2114.

Sweeney, J.J., and Burnham, A.K., 1990, Evaluation of a simple model of vitrinite reflectance based on chemical kinetics: American Association of Petroleum Geologists Bulletin, v. 74, p. 1559-1570. 
Tsuzuki, N., Takeda, N., Suzuki, M., and Yokoi, K., 1999, The kinetic modeling of oil cracking by hydrothermal pyrolysis experiments: International Journal of Coal Geology, v. 39, p. $227-250$.

Waples, D.W., Pacheco, Jorge, and Vera, Alfredo, 2004, A method for correcting log-derived temperatures in deep wells, calibrated in the Gulf of Mexico: Petroleum Geoscience, v. 10, no. 3, p. 239-245.

Wrygala, B.P., 1989, Integrated study of an oil field in the southern Po basin, northern Italy: Juelich, University of Koln, Ph.D. dissertation, 217 p. 
Publishing support provided by:

Denver Publishing Service Center, Denver, Colorado

Manuscript approved for publication, March 2008

Edited by Mary A. Kidd

Layout by Sharon Powers 
